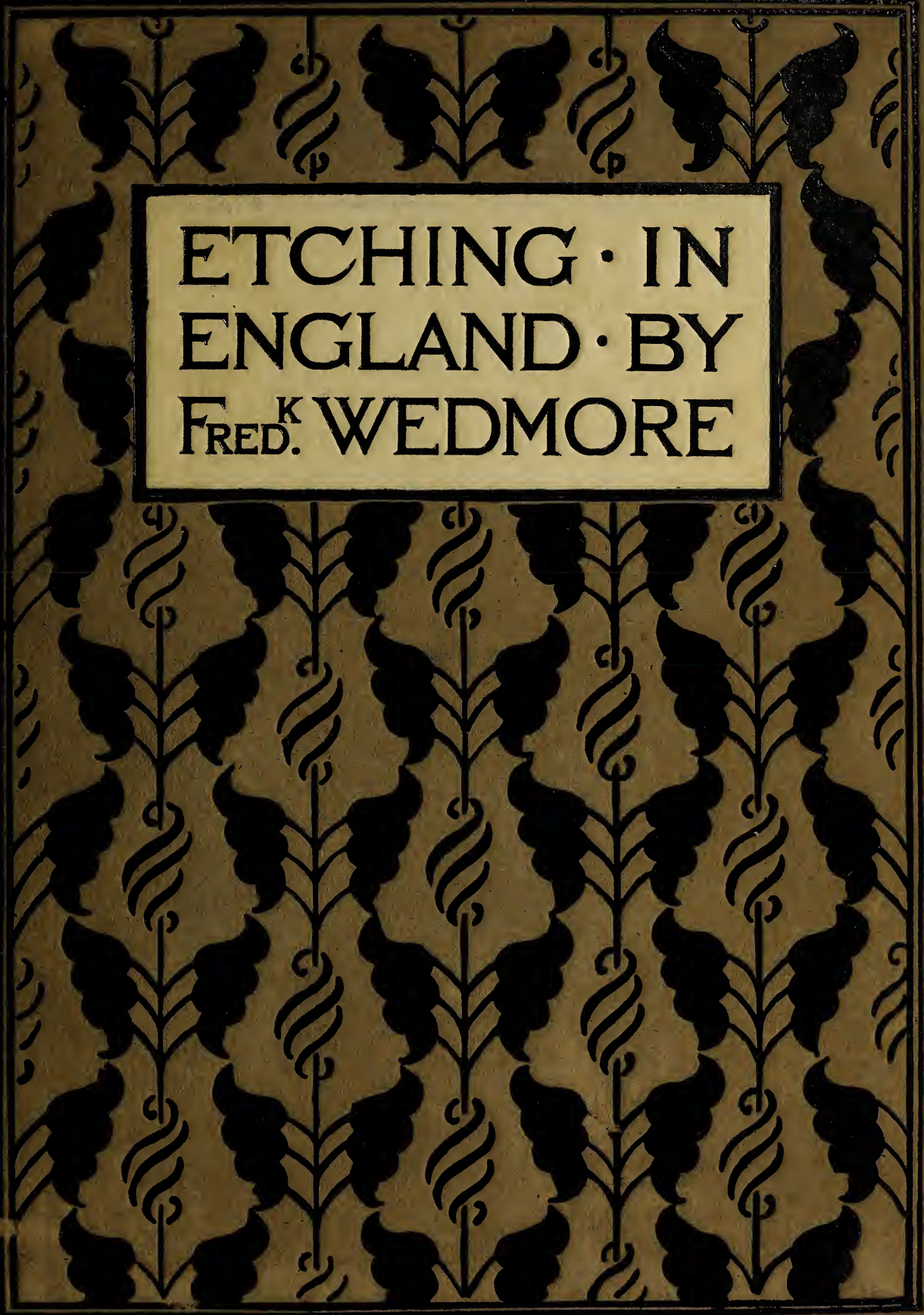


SMITHSONIAN INSTITUTION 590. 




Etching in England 




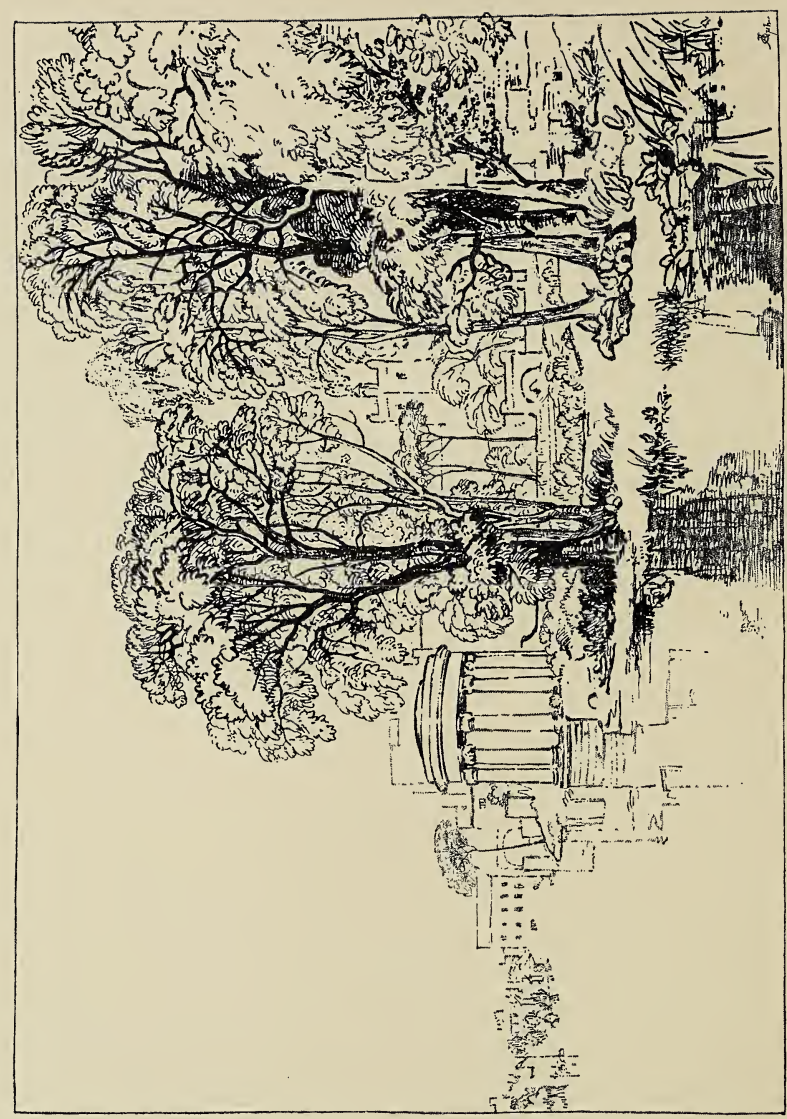




\title{
Etching in England by
}

Frederick Wedmore

\author{
With 50 Illustrations
}

London

George Bell and Sons

I 895 



\section{PREFACE.}

I READ, the other day, in a note of Abraham Hayward's to his translation of "Faust," how Schlegel wrote of Geethe-to $M$. de Rémusat,--"Il n'aimait guère à donner desexplications, et iln'a jamais voulu faire des préfaces." It would not be seemly, perhaps, that in the present volume of brief historical and critical record, I should endeavour to imitate so angust a silence.

Twenty-seven years have passed since one of the most interesting and judicial of English writers upon Fine Art published the book which did amongst us the service of popularising, in some degree at least, the knowledge of Etching. The craft of the aquafortist has, since then, become a medium of expression generally accepted, if not precisely understood; and the halfeducated young woman of our period, far from considering the art of whose achievements I treat, as " a form of elegant pendrawing," (as she did in Mr. Hamerton's 
first days), is likely perhaps to hold-with "Carry," in my own little story - that there is "nothing in the world so artistic as a very large etching." The public, if it has not become properly instructed in the technique of Etching, has at least had the opportunity of becoming so. Hence I have conceived it to be no part of my business to discourse much upon methods. For them the reader may turn now, not only to Mr. Hamerton, but to Sir Seymour Haden, with his great practical experience, his native endowments, and his finely trained taste; to $M r$. Herkomer, with his frank and interesting personal record; to $M$. Maxime Lalanne; to Mr. Frank Short-but the list is too long for me to attempt to exhaust it.

What is done here-and done I think for the first time-is to devote a book to the survey, not of good etched work generally, nor of all etched work-all popular etched work-wrought in England, but of such work as has been wrought in England of the finer and truer kind. That has led to many omissions; for, in the last generation and before it, people were popular-as many are to-day-who were clever dranghtsmen, perhaps, but bad etchers. It has led, too, 
to many inclusions-inclusions not possible to Mr. Hamerton. Much of the best work done in England has been done since he wrote; and a littie excellent work, done long before he wrote, he happened to pass over.

This present book, then, is devoted to the best English art. It treats of the foreigner only when he has laboured much in our land, or-I am thinking perhaps of $M$. Helleu-has at least been much associated with it. It includes necessarily a great American-Mr. Whistler-who was amongst us for more than thirty years - and a man of French birth who has been half his life with us-M. Legros. The art of Etching is not, it may be, like the art of Water-Colour, essentially English; but I suppose that nowhere more than here has it been practised with excellence and with legitimate variety. And this I say with the full knowledge that the achievements of Rembrandt have made Holland classic ground for ever for the lover of Etching, and that the history of that art in France includes two names, at least, which are inevitably illustrious-Méryon's name and Jacquemart's.

LONDON: October, 1895.

$$
\text { F. } W \text {. }
$$





\section{CONTENTS.}

I. Two Classes of Etching . . . . . I

II. TURNER . . . . . . . . . . . . . . . 3

III. GIRTON . . . . . . . . . . . . 6

IV. WILKIE. . . . . . . . . . . . . IO

V. GEDDES. . . . . . . . . . . . . 14

VI. Crome . . . . . . . . . . . . . 20

VII. COTMAN . . . . . . . . . . . . . 22

Vili. Samuel Palmer . . . . . . . . . . 26

IX. JAMES MCNeil Whistler . . . . 30

X. Sir Seymour HadeN . . . . . . . 45

XI. Alphonse Legros . . . . . . . . 62

XII. William Strang. . . . . . . . . 7 I

XIII. Charles Holroyd . . . . . . . . 87

XIV. FRANK SHORT . . . . . . . . . . 95

XV. C. J. WATSON . . . . . . . . . . IO3

XVI. Oliver Hall . . . . . . . . . . II5

XVII. Colonel GofF. . . . . . . . . . II9

XVIII. D. Y. CAMERON . . . . . . . . . I37

XIX. Joseph Pennell . . . . . . . . . 140

XX. Mortimer Menpes . . . . . . . . 144

XXI. L. RAVEN-HILL . . . . . . . . . . 148

XXII. R. W. Macbeth, Hubert Herkomer, R.A., AND AXEL HAIG. . . . . 152

XXIII. SOME OTHER ETCHERS. . . . . . . I59

XXIV. HelleU . . . . . . . . . . . . I72 



\section{ILLUSTRATIONS. $^{1}$}

I. Twickenham (Frontispiece) . . . . Turner

2. SeIne BRIDGE . . . . . . . Girtin 7

3. The RECEIPT . . . . . . . . . Wilkie II

4. Pechham Rye. . . . . . . . Geddes I5

5. HALliford ON THAMES . . . . . " " I7

6. Near Whitby . . . . . . . . Cotman 23

7. The Herdsman . . . . . Samuel Palmer 27

8. Thames Police . . . . . . . Whistler 33

9. The Piazzetta . . . . . . . . " 39

Io. Tree Study . . . . . . Seymour Haden 43

i I. Thomas Haden, after Wright of Derby

12. Kidwelly Town. . . . . " " " 49

$\begin{array}{ccc}\text { Seymour Haden } & 47 \\ ., & " & 49 \\ , & , & 53\end{array}$

I3. A Water Meadow . . . . " " " 53

14. WiNDMILL HILL . . . . . " " " 55

I5. SCOTCH FIRS . . . . . . " " 59

i6. Communion dans l'Église St. Médard

Legros 63

I7. LA MORT ET LE BÛCHERON . . . " 67

I8. The Potato Basket . . William Strang 73

I9. The Bookstall . . . . " " 75

20. LORD Justice LindLey . . " " " 77

2I. Midnight Mass, Monte Oliveto

Charles Holroyd 8I

${ }^{1}$ In nearly every case the illustration is more or less reduced from the original. 

23. Round Temple . . . . . " " 85 24. Wrought NAILS. . . . . . Frank Short 89 25. Sleeping till the Flood . : " " 9 I 26. QUARTER Boys . . . . . . " ” 93 27. Mill Bridge, Bosham . . . C. J. Watson 99 28. ST. ETIENNE DU MONT . . . , " IOI 29. LANDSCAPE With TREes . . . Oliver Hall io7 30. ROADSIDE TREES . . . . . . " " " IO9 3I. TREES ON THE HILl-SIDE . . " " II 32. The Edge of the Forest. . , , II 3 33. Chain Pier, Brighton . . . Colonel Goff i i 7 34. Norfolk Bridge, Shoreham . " " I 23 35. Pine Trees, Christchurch . " " I27 36. Border Towers. . . . . D. Y. Cameron I3 I 37. The Palace, Stirling Castle , , " I33 38. Windmills, ZandaAM. . . ” ”I 35 39. Le Puy en Velay . . . . Joseph Pennell i4 40. JAPANESE Girls . . . . . . . . Menpes 145 4I. WANDLE RIVER . . . . . L. Raven-Hill I49 42. GWENYDD . . . . . . . . . Herkomer I 53 43. The Open Window . Elizabeth Armstrong I 57 44. At the Loom . . . . Minna Bolingbroke $16 \mathrm{I}$ 45. Dorking. . . . . . . . Percy Thomas 163 46. SunRise in WAles. . . W. Holmes May I67 47. A Hurrying Wind . . . . Alfred East 169 48. Etude de Jeune Fille . . . . . Helleu I73 49. Femme À la TASSE. . . . . . . " I77 50. Le Salon Blanc . . . . . . . , I8I 


\section{ETCHING IN ENGLAND.}

I.

\section{TWO CLASSES OF ETCHING.}

$\mathrm{S}$ in France and America, so, very
specially, in England, the produc-
tions of the etcher have to be divided broadly into two classes, one of which is the result mainly of a commercial demand, and the other, of an artistic impulse. The etcher whose employment of the etching-needle is confined wholly, or confined in the main, to the work of realizing and translating the conceptions of another, is, like the reproductive line-engraver, or the reproductive engraver in mezzotint, little more than the dexterous instrument which carries another's message. So artistic is his process, when it is properly used, that it is preferable indeed that he be himself an artist as well as a craftsman-it is indeed essential that he shall have some measure of artistic feeling, as well as the flexibility of the executant. 
But our demands upon him stop, in any case, at a comparatively early point; and we find him more or less sharply cut off in our minds, and in our estimation, from the artist who, when he employs the etchingneedle, is occupied with the spontaneous expression of his own thought and fancyof the particular things of beauty and of interest which may strike him on his way through the world. 


\section{II. \\ TURNER.}

F fine original etchers within the confines of these realms, Turner was almost the first to appear. He was the senior, considerably, of Wilkie and Geddes, who will have to be spoken of soon after him. During twelve years of his "early middle" period-between 1807 and I8I9he wrought what were in some respects important etchings upon something like seventy plates. But his etchings differed in aim, as well as in execution, from almost all the others I shall speak of in this brief general survey of the achievements, here in England, of the etcher's art. They did so partly by reason of the fact that it was never intended that they should be complete in themselves. They laid the basis of an effect which had to be completed by the employment of another art. They did hardly more than record-though always with an unequalled power and an unerring skill-the leading lines of those great landscape compositions 
which the mezzotint of the engraver (and the engraver was often Turner himself) endowed with light and shade and atmosphere. For it was by a union of these two arts that that noble publication was produced whose business it was to surpass in variety and subtlety the "Liber Veritatis" of Claude.

It is very possible that in some of the plates of his "Liber Studiorum," Turner did not undertake the "biting-in," with acid, of those subjects whose draughtsmanship was his own. Probably he did in all the best of them. In an etching, the strength and the perfection of the result-the relation of part to part-is dependent so much on the biting. It is hardly conceivable that where the etchings of the "Liber Studiorum" strike us as most noble, they were not wholly-in biting as well as in draughtsmanship-Turner's own.

They differ much in merit, apart, I think, from the necessary difference in interest which arises from the opportunity given by one subject and denied by another for the exercise of an etcher's skill. They have generally, within their proper limits, perfect freedom of handling, and an almost incomparable vigour, and a variety which liberates their author from any charge of mannerism. There are few of them which could not hold their own with any plate of Rembrandt's done under conditions sufficiently resemb- 
ling theirs. The etching of the "Severn and Wye," or the etching of "St. Catherine's Hill, Guildford," is carried very nearly as far as the etching of the "Cottage with White Palings," and with a result very nearly as delightful and distinguished. And in regard to the average etching of Turner, it may fairly be said that a hand put in to pluck out of a portfolio by chance any one of the seventy, would discover that it held a print which was at least the equal of that one of Rembrandt's with which it is fairest of all to compare it-a print of Rembrandt's done, like Turner's, for "leading lines " alone-I mean the famous little tour de force, the "Six's Bridge."

So much for the greatness of our English master. I pass from him with this reminder, given again for final word. Wonderful as is his etching for selection of line, wonderful for firmness of hand, we must never allow ourselves to forget that it was not intended to present, that it was not intended to be in any way concerned with, the whole of a picture. 


\section{III. \\ GIRTIN.}

7 HE limitations which we have marked

1 in Turner's aim in Etching, are to be noticed just as clearly in the aim of Girtin. Nay, they are to be noticed yet more. For while Turner not infrequently gave emphasis to his work by the depth and vigour of his bitten line, Girtin, in his few and rare etchings-which, it is worth while to remember, just preceded Turner's-sought only to establish the composition and the outline. He did this with a skill of selection scarcely less than Turner's own, and admirable, almost as in his water-colour work, is the quiet sobriety of his picturesque record.

But though Girtin's etchings-many soft-ground, and about twenty-may contain some lessons for the craftsman, some indeed for the artist, they are scarcely for the portfolios of the collector. They were wrought, all of them, towards the end of Girtin's life, that was cut short in 1802 , 


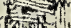

$\mathrm{CO}^{3}$

$4 \sin 3$

$3 x=2-4$ -

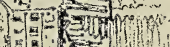

(4)

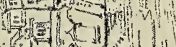

(70) $(x)$

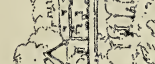

in

Eni

in:

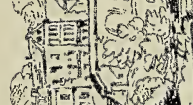

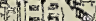

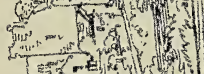

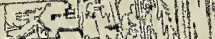

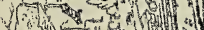

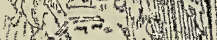

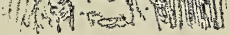

管 

when he was twenty-nine years old. They were the preparations for his aquatinted plates of Paris, against which in their completed form there is only this to be saidthat the avoidance, generally, of any attempt at atmospheric effects, involves a seeming monotony of treatment, though as dignified visions of old Parisian architecture, of $\mathrm{Pa}$ risian landscape, so to speak, in its habitual setting of wide sky and noble river, they have never been surpassed, and very seldom equalled.

The vision of Girtin, it must always be remembered-whatever be his work-is not emphatically personal. With all his charm and breadth and dignity, something of the pure architectural draughtsman lingered to the end, in his labour. He had no parti pris about the facts: no bias we forgive, no prejudice we welcome. He sought to represent simply the "view," although no doubt the "view" was generally bettered by his artistry. 


\section{IV.}

\section{WILKIE.}

FAMOUS Scotchman, David Wilkie, $A$ and his very distinguished friend and fellow-countryman, Andrew Geddes, wrought, each of them, in the middle period of Turner's life, a certain number of etchings of independent merit. Those of Sir David Wilkie, which were but few, happen to be the best known, because Wilkie, much more than Geddes, was a leader of painting. But, meritorious as are the etchings of Wilkie, in their faithful record of character and picturesque effect, they are seldom as admirable as the prints of his less eminent brother. They have, generally, not so much freedom; and, while they follow great traditions less, they are at the same time less individual. "Pope Examining a Censer" has the dignity of the designer and the draughtsman, but not much of the etcher's particulargift. "The Receipt" -or "A Gentleman Searching in a Bureau," 


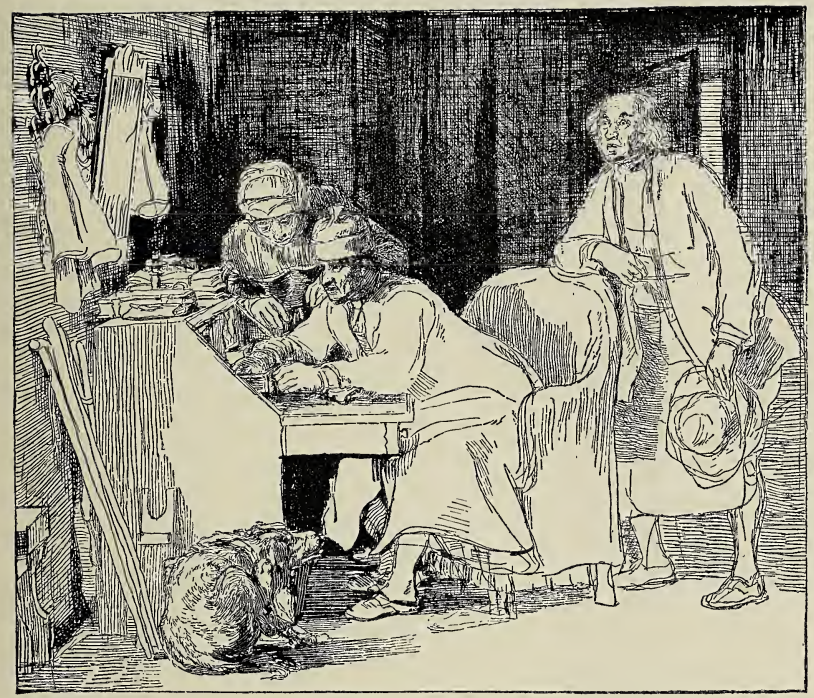

DAVID WILKIE.

"THE RECEIPT." 

WILKIE.

for this second title explains the subject better-is the most successful of Wilkie's. It is characteristic of his simpler and less ambitious genre, and is indeed faultless, and more than faultless-charming. 


\section{V. \\ GEDDES.}

NDREW GEDDES etched fouror five A times as many plates as Wilkie. He issued ten from Brook Street, Grosvenor Square, in 1826 . The dates on some of them are 1812,1816 , and 1822 ; and, besides these ten that were published, about thirty more, which there was no attempt to issue to the world, have to be taken account of. Some, like the excellent "Portrait of the Painter's Mother"-which is so fine in illumination, in drawing, and in character - are directly suggested by the artist's paintings. Others-including all the landscapes-are, apparently, studies from Nature, done with a singular appreciation of the ripest art of Rembrandt.

Geddes was very sensible of the charm of dry-point-of its peculiar quality of giving individuality to each one of the few impressions which you may safely produce from it, and of its unique capacity for rendering broad effects of light and shade. 


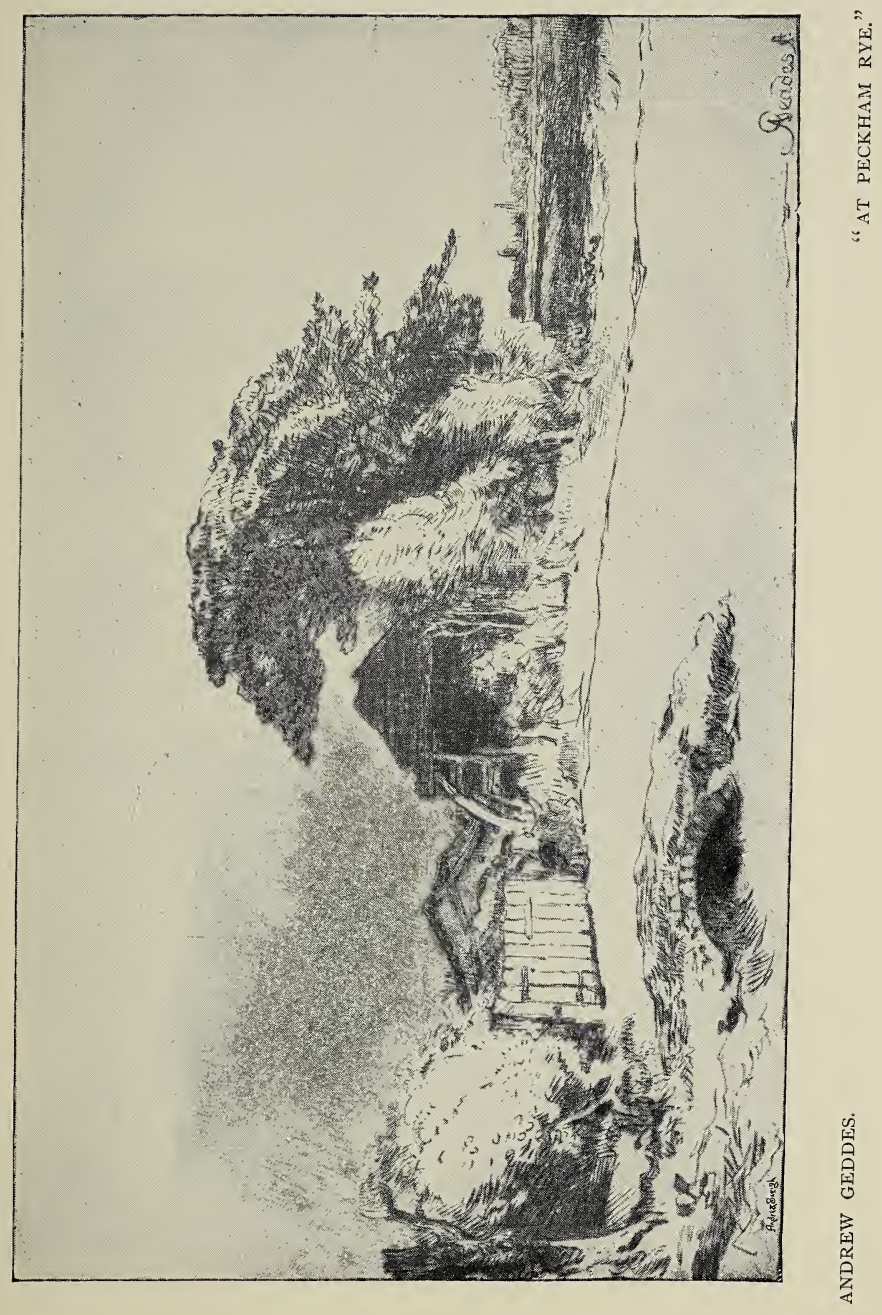




The "Peckham Rye" shows this. Nothing can show it better. And there is at least one other plate by Geddes, "Halliford on Thames," which proves him just as completely a master of elegance and grace of line as "Peckham Rye" shows him a decisive master of masculine effect, and curiously adept in the broad and balanced disposition of masses of light and shade.

Geddes's work will not decline in value, and the connoisseur has no business whatever to forget or to ignore it. Only, if he collects the dry-points of Geddes, he had better wait for years, if necessary, for early impressions of them, and he had better repudiate altogether the unsatisfactory modern edition-the worthy Mr. David Laing's volume, "Etchings by Wilkie and Geddes," issued, with the best intentions in the world, in Edinburgh in 1875 . 


\section{VI. \\ CROME.}

T $\mathrm{T}$ is the splendid work of Crome among the Norfolk coppices-among the fields studded here and there with cattle, but chiefly in the tangle of the wood, or where the wood-path winds under the rustic palings, and then through undergrowth, and out into the rising meadow, to be lost at last, a thread against the horizon sky-it is this splendid tree-work, large, massive, intricate, pictorial, never narrowly faithful alone, that gives interest and value to Crome's series of etchings. He did them mostly in the last years of his life (which closed in I82I), and it was always for pleasure and remembrance that he wrought them. Publication he cannot have intended, for he never did enough to be recognized a master while he lived, and his etched subjects gave him memoranda for his pictures, and were little records of places that he loved.

Their merits came slowly to be known 
by some few; and the etchings, carelessly printed and ill-bitten, were given, here and there, by Crome to his friends. In 1834 , his widow, I am told, issued an edition, which must have been very small, and four years later they came again in a measure before the lovers of Norfolk art, re-bitten by one Mr. Ninham, re-touched by one Mr. Edwards of Bungay, and issued with a short biography by Mr. Dawson Turner -a volume which may still be stumbled on at the booksellers. These later states are of slight artistic value. They tell us little of Crome which we may not know much better from other sources he has furnished, and much of their work is not Crome's at all. The early states are, at least, "signed all over" by him. Amateurish enough in biting and in printing, they are yet pleasant, characteristic records. "At Bawburgh," and "Near Hingham" (dated I8I3), and "At Woodrising" are some of those that one would like to cherish: and cherished they ought to be, for the reasons I have named. Yet to put them beside even less admirable works which have enjoyed the ordinary conditions of fair presentationthe biting adequate, the printing careful, and the paper good-is to see them, of necessity, at a disadvantage. 


\section{VII. \\ COTMAN.}

COTMAN'S etchings-soft ground, for the most part-are scarcely for the average collector, any more than Crome's. No one, I mean, puts them carefully in the cabinet, or, with reverence, in the shrine and sanctuary of the solander box; but, in book-form, they stand, and should stand, on the shelves of some lovers of Art. One not unwieldy volume-that "Liber Studiorum," which, in the year I838, Cotman brought together, not perhaps without thought of Turner's accomplished triumph - contains two score or so of plates which show much, not only of Cotman's capacity as a draughtsman, but of his genius for ideal composition, of his faculty for dignity of line, and for so disposing masses of light and shade that they should be not only significant, but impressive. It is here seen that this glorious and original colourist could dispense with colour and yet be fine and individual. Yet, as achievements in 


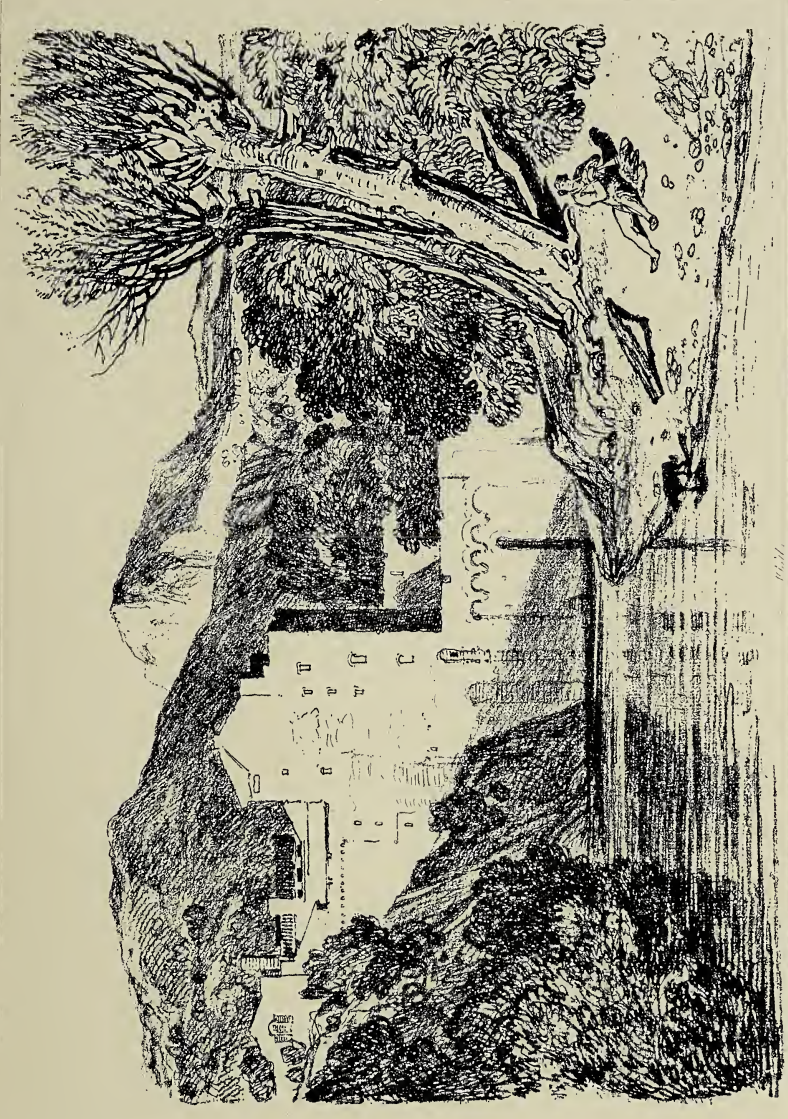



芯 

the art of Black-and-White, no careful student could place them in line with the plates of the admitted masters of etching. They have not often the subtlety of technique which, allied of course with fineness of conception, is the very sign of the master. Still, they are too good to be passed by in silence. And they are a great man's work. 
CAMUEL PALMER-an English clasSic, by this time, as a painter of watercolours-made (from the year I850, or thereabouts, onward to his old age in the seventies) a limited number of elaborate etchings in which the play of line is almost wholly lost: more lost, much more lost, than in the etchings of Méryon. But Samuel Palmer, like Méryon, was a great poetic artist. Slowly he built up his effects, his noble sunrise or sunset landscapes-the landscape of artistic convention and poetic vision. The unity and strength of his thought was never sacrificed or frittered by the elaboration of his labour. To condemn him then, because he was not a free sketcher, would be as pedantic as to condemn Méryon. Nay more, were any such pedantic condemnation meted out to him, it would have to be meted out to the author of the "Ephraim Bonus" in his turn; since it is a characteristic of Rembrandt that in 


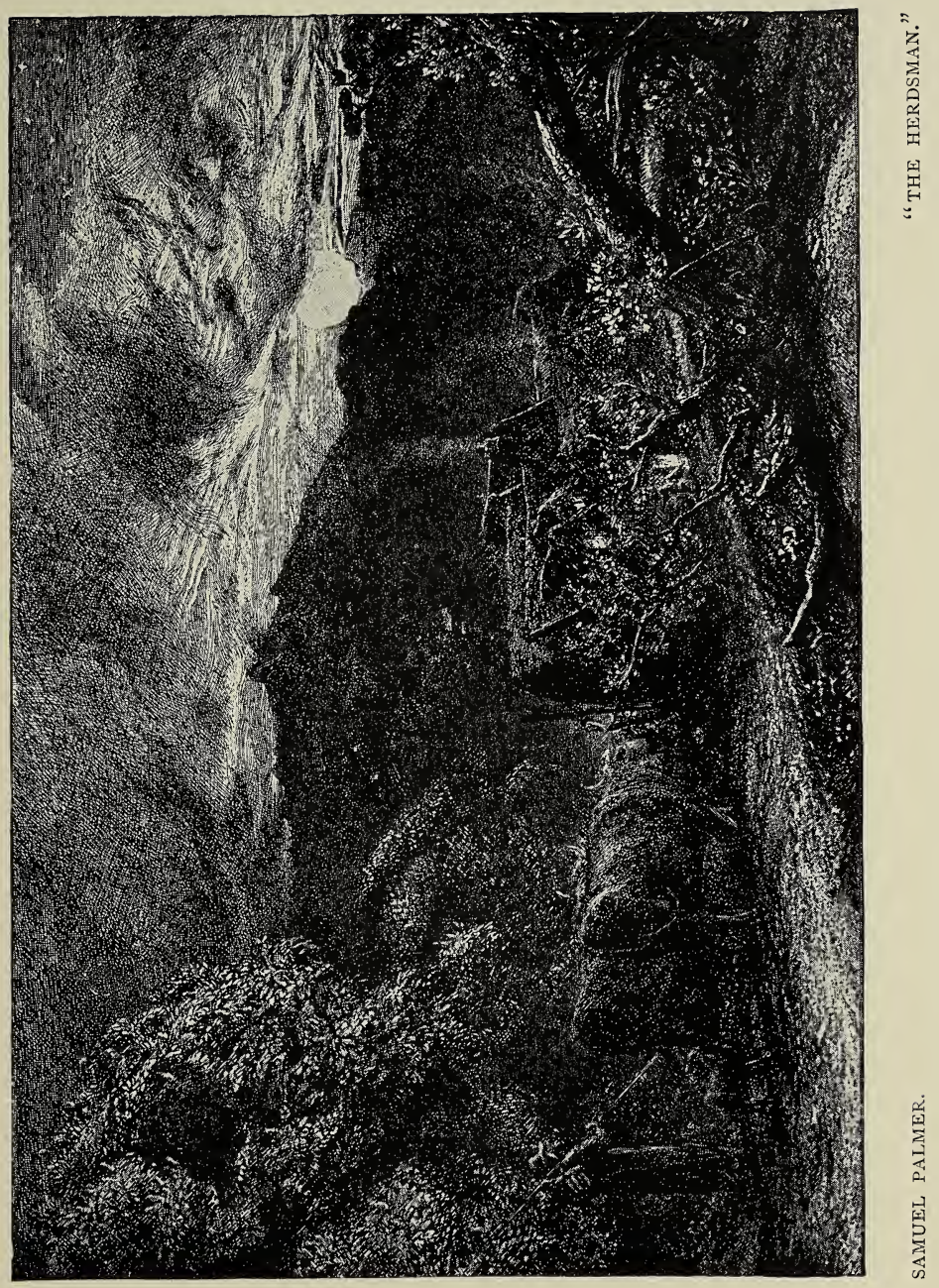



his engraved as in his painted work he allowed himself an amazing elasticity of method. Rembrandt, like every great man, is super grammaticam. He was a law unto himself. And so, in a measure, was Samuel Palmer, the creator of the solemn plates of "The Early Ploughman" and "The Herdsman," and of certain hardly less admirable coppers which illustrate his own translation of the Eclogues of Virgil. 


\section{IX}

\section{WHISTLER.}

T PASS from the brief mention of a 1 dignified artist, high of soul-whose work is charged with reverie, grandeur, admonishment-to the consideration of an artist little concerned, in emotional or reflective or didactic way at least, with Humanity's fortunes, but the most skilled wielder of the etching-needle whom the world has seen since Rembrandt.

Mr. Whistler's scarcely sympathetic attitude towards his kind may be occasioned in part by the conviction that it is his kind's most urgent business to be concerned with his prints, and his knowledge that this conviction of his own-if thus I dare to call it - has not, until the last few years, been largely shared by other people. Popular he could not be; or scarcely in his own time. A Sarasate, with his music, attracts the world; but in pictorial art of every sort the virtuoso appeals only to his brethren. His "brethren"- -his real brethren-are 
quite as likely incleed to be connoisscurs as fellow-workmen. But "brethren" shall be the word. And it is such who-some of them for more than thirty years, and some of them since yesterday-have recognized the genius of Whistler.

Our admirable comedian, Mr. Toole, isif I may recall the saying of one of his fellow artists-commonly supposed to have been born in every town of the English provinces, in which the receipts, when he visits it, do their part to justify that town in claiming him as a native. Not quite for the same reason there are towns which dispute with Baltimore the honour of having given birth to the artist of the "French Set," the "Thames Set," and the "TwentySix Etchings." Mr. Whistler was born, anyhow, of American parents-I like Baltimore so much, that I hope it is only Baltimore that can fairly claim him-and it is stated to have been in July, I834, that he came into the world. ${ }^{1}$ American then by birth, or family association, he is to a great extent French by education, and his first dated etchings, of the year 1857, were wrought when he was a student in Paris. Along with a popular English draughtsman of Society, he was in the studio of Gleyre,

1 The editor of "The Magazine of Art" has assured me, in its pages, that Mr. Whistler swore in Court that he was born in St. Petersburg. 
and to Gleyre, for all that I know, he may owe something; but no debt is apparent in his work. A few etchings wrought in Paris, and a few during a journey in Alsace and Lorraine, and then in I 859 we find Whistler settled in London and busy with the laborious series of etchings of the Thames.

He was himself almost from the beginning, though it is possible to trace the influence of even minor Dutch etchers, or Dutch painters at all events, in such a tentative little work as "The Dutchman Holding the Glass," and though in the nobler plates known as the "Rag-Gatherers," "La Vieille aux Loques," "La Marchande de Moutarde," and "The Kitchen," it is clear that Whistler in his conception of a subject was scarcely without reverent thought of the great masters of pathetic suggestion and poetic chiaroscuro-Rembrandt, De Hooch, and Nicholas Maes. But by the time he executed the most justly famous etchings of the Thames set - the most famous of the "Sixteen Etchings," such as "Black Lion Wharf," "The Pool," and "Thames Police"- -he was himself, wholly. He was in full possession of what may be called his earlier manner. Nay, in December, 1859-not many months after these things had been wrought with a minuteness of detail which the art of Van der Heyden or of Hollar could not have ex- 


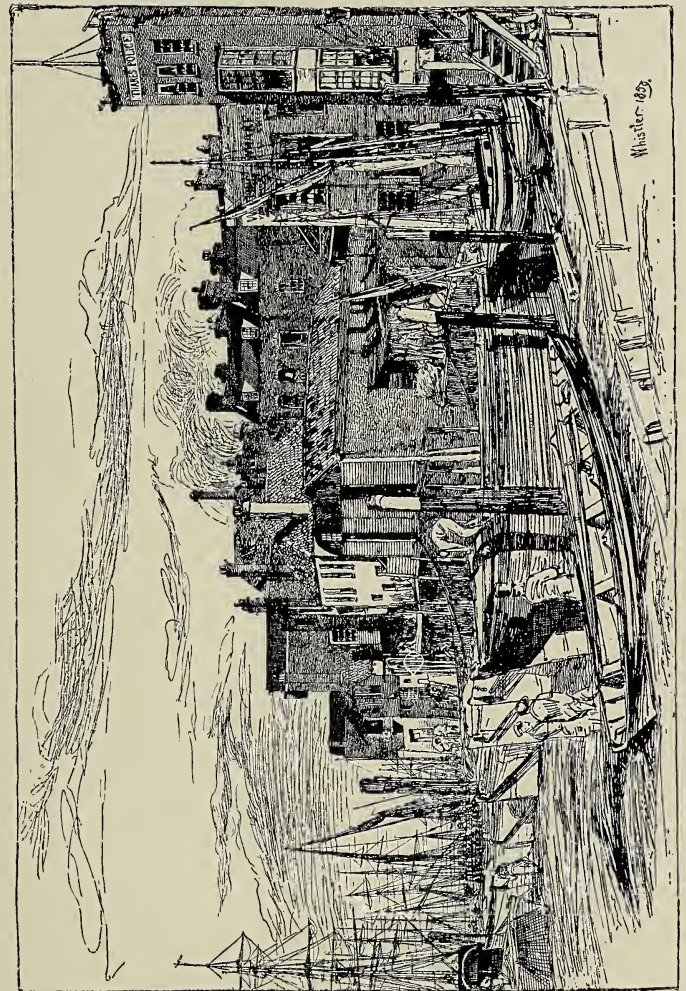



celled-we find in one unfinished plate of extreme interest and extraordinary rarity ("Paris: Isle de la Cité") some union of his earlier realization with his later suggestiveness.

The early detail of Whistler, in the Thames etchings, is never for a moment dull. $\mathrm{He}$ puts down for us on the copper endless results of endless and interesting observation. The life of the River, "below bridge," and the life of riverside London is all therebarge and bargee, crane and warehouse, wharf and chimney, clipper and wherry, and the sluggish stream, the flat horizon, the distant river-curve, the tower of Rotherhithe Church, rising perhaps from out of the remote and low-lying roofs. And, elaborate as the work is, it is never for a moment either fatigued or mechanical: it preserves inviolate the freshness and vivacity which it is the province of the etching to retain. Nor does the work of Whistler, either at this period or later, ever lose sight of that which, again, it is the etcher's special business to cultivate-the value of pure "line." By " pure," I do not mean Classic (Classic line has other functions): I mean the line that is expressive-that is set with a purpose; that, being laid, is not interfered with - the line that lives and that tells its story. By 1863 - as is shown by the exquisite "Chelsea Wharf," with its quiet of the 
suburban afternoon, and by the admirable "Amsterdam," with its houses, its shipping, its thin line of long flat coast under a wildish sky ${ }^{1}$ - Whistler had thoroughly entered upon the work of his middle period. A manner more suggestive to the expert, and more economical to the artist, though received less readily by the first-comer, was by this time clearly upon him; and, with certain modifications, it has continued to this day. Perhaps it is most distinctly marked in that Leyland period-a period of the rare dry-points of the Leyland family -which, after a little interval, succeeded the period of the "Chelsea Wharf" and the "Amsterdam." It is in its perfection in "The Model Resting" (1870), in "Fanny Leyland" (1873), and in "Dam Wood" (1875)-all of them rare, desirable, notable plates of the true Leyland period, in most of which, as in some of his later work, Mr. Whistler would seem-if I may put it soto have painted upon the plate as much as drawn: to have sought, that is, painter's as well as draughtsman's qualities.

I endeavour to note the distinctions, but after some fourteen years of close study of Mr. Whistler's works-and of fruitful enjoyment of their possession-I must still guard

1 The wildish sky is to be found only in the First State, it is non-existent in the second, which is yet a charming thing, in its own way. 
myself against expressing any marked preference for one period over another. The work of each period has its own qualities, and, since all Art is concession and compromise, the work of each period may have likewise its own deficiencies. Practically there has been no "bad time;" but at more times than one there have been-even from this gifted hand-unsatisfactory, unworthy prints.

In 1879, the great etcher went to Venice, at the instance of the Fine Art Society, and there, in line extraordinarily expressive and vivacious, he recorded, not so much the recognized beauties of the town, as the vividness and variety of his personal impressions. That was his true business. Some of these etchings were exhibited before they were properly finished-finer effects remained, I mean, to be obtained from the plates. Hence they were received, perhaps, with more than customary coldness, though the fairy-like " Little Venice," nearly perfect to begin with, was always an exception to the rule. There is nothing of Rembrandt's, there is nothing of Méryon's, besides which this diminutive masterpiece may not most fitly be placed. Power of selection, power of composition, delicacy of handling, all say their last word in the "Little Venice." Art does not go any further. 
Since I880, when they were first exhibited, many of the plates done in Venice have been taken up and perfected. The "Piazzetta," for instance-unattractive at first: a ragged thing, or a skeleton-has somewhat lately been brought to the highest level that is attained by any etcher's art. And, several years ago, Mr. Whistler perfected for the limited issue by the Messrs. Dowdeswell, the "Twenty-six" platesmost of them Venetian in theme-which had, fortunately, been bought by hardly anybody (I may suppose) until, in I886, their excellence was achieved. In this set, the entrancing freedom and inexhaustible suggestiveness of "The Balcony" and "The Garden" demand note: the balcony that, with drapery flung upon it, hangs over and overlooks the Grand Canal: the garden which passing humanity peers into, and peering, perhaps reflects with the Greek poet whose youth was gone:

"Spring for the tree and herb ; no spring for us."

It was in 1886 that I published my "Whistler's Etchings: a Study and a Catalogue." About two hundred and fourteen etchings had then been executed; and these-the work of what must necessarily be the better part of Mr. Whistler's lifetime-were carefully described as well as appreciated. I hope the book was not 


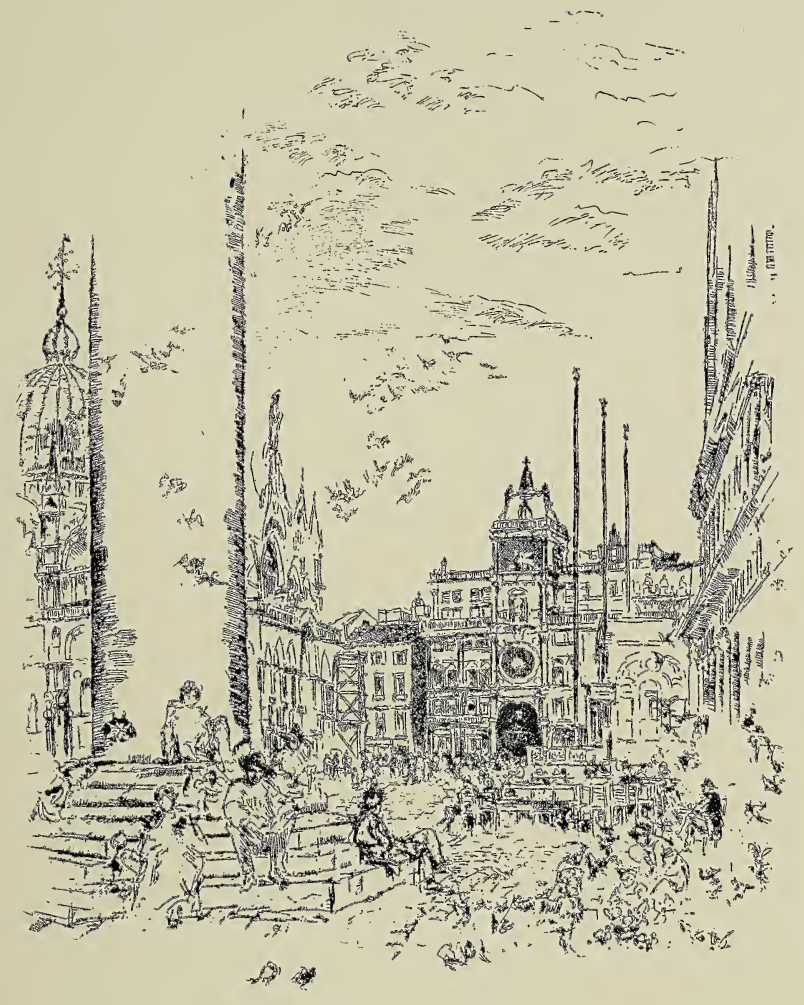

J. MCNEI, WHISTLER:

"THE PIAZZETTA." 

without effect, in England and America, on the demand for Mr. Whistler's prints, many of which, however, were already unobtainable, so narrowly limited had been their issue, and so various, during all those years, the fortunes of the plates. But if old etchings were difficult to get, new ones were not wanting. There cropped up, under my notice, ingenious but insignificant croquis, declared by dealers, interested in them, to be valuable, because they were "undescribed." Why were they "undescribed?" Because, it seems, they had only at that moment been done. Plates with a few scratches on them-clever, since they were Whistler's, but each plate less important than the last-passed quickly into the hands of men who had, presumably, much money and only a little knowledge.

During the last five or six years, with a creditable and natural reaction from what would seem to have been a fever of immature fruitfulness - in the midst of which, after all, this exquisite and ever dainty artist did, of course, nothing ugly, t hough much that was rather provokingly thinMr. Whistler has, from time to time, produced a few new plates of serious interest and of finest accomplishment. The Brussels group belongs, in spirit, if not precisely in fact, to these latest years; and charming is the seeming intricacy, yet assured lightness, 
of the Whistlerian treatment of Flemish house-front. Again, there are delightful little things wrought in the country of the Loire: not solid records, but, as it were, fleeting visions of its architecture, and very fascinating. But the best of all the later work, and it is among the very latest that has yet been seen, is the quite admirable "Zaandam," over whose stretched line the breeze from across dyke and fen and Zuyder Zee, stirs here, stirs there, stirs everywhere, the wings of the windmills of Holland. 


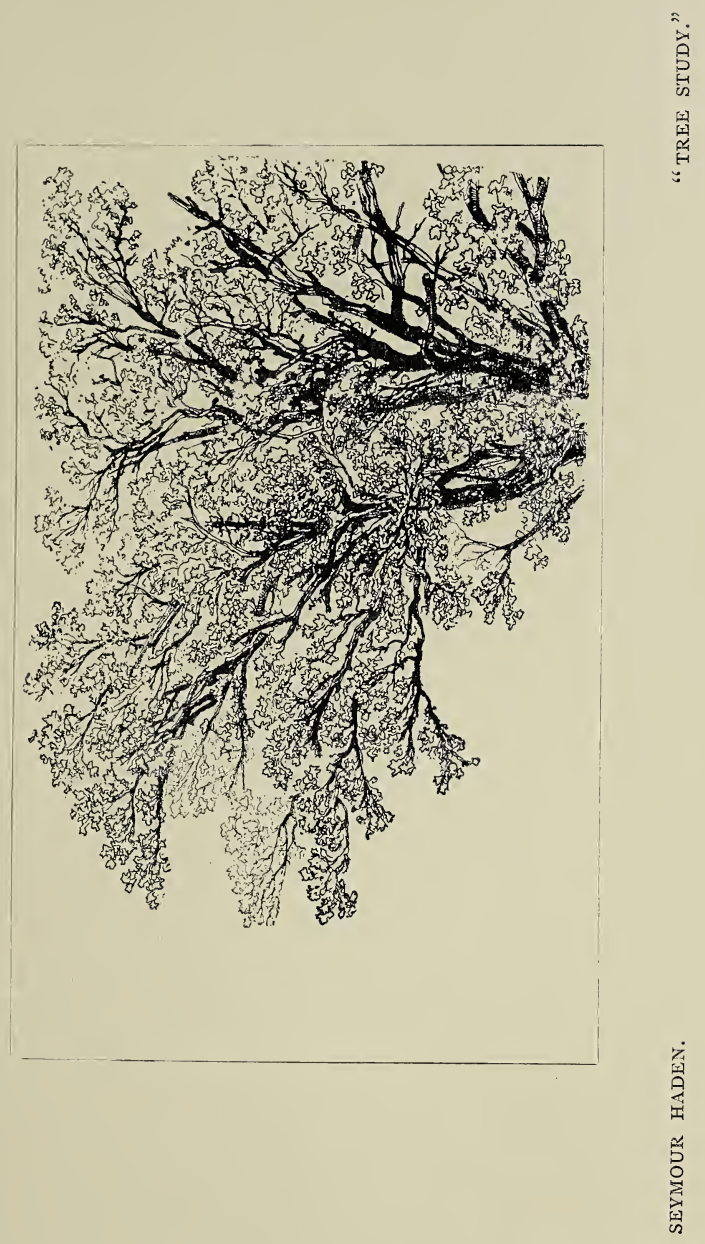





\section{$\mathrm{X}$. \\ SEYMOUR HADEN.}

SEVERAL years before Mr. Whistler $S$ etched at all-in I843 and 1844 indeed - a now veteran artist, President "de sa propre Académie," who has been famous surgeon as well as famous etcher-founder of the Royal Society of Painter-Etchers, energetic advocate, by speech and writing, of the art he loves-drew delicately upon six tiny plates what were meant to be the beginnings of landscapes in mid-Italy. As rare as anything in Mr. Whistler's long cenvre-though, as their author knows, in themselves far less desirable-are the impressions of those little plates, which few have seen, but which I beheld, perhaps ten or twelve years ago, strengthened here and there with pencil-work, yet even then only feebly holding their own, among the abundant treasures of an upper chamber in Hertford Street - the almost unknown initial chapter, they, in the sturdy and now celebrated volume of Seymour Haden's etched work. 
The days when they were executed were about the days of the Etching Club, a body which in its turn was followed by the Junior Etching Club. These clubs left us no legacy we care to inherit; their productions were for the most part fidgety, prim, at best desperately pretty and ridiculously elaborated, so that there was practically nothing in them of visible and expressive line. A little-just a little-of that visible line there was-there actually was, even in an unenlightened period-in those few trifling plates of Seymour Haden's on which his first work was accomplished. He wrought nothing for many years afterwards. Then, in $185^{8}$, when Whistler, by this time his brother-inlaw, was already busy, Seymour Hadenurged thereto by the knowledge of good work executed in France at that moment, and by a fitting reverence for the master etchings of Rembrandt-took up some coppers seriously; and he set down upon them, in this and the few following years, with an appreciation not less certain and immediate than Mr. Whistler's of those laws to which etchings should conform, his powerful and personal impressions of English landscape, of the trout stream, and the stately river, of forest trees, a sunset over the Thames, of the yews and cedars of an English country-house ("Mytton Hall"), of the reflections, in some quiet 


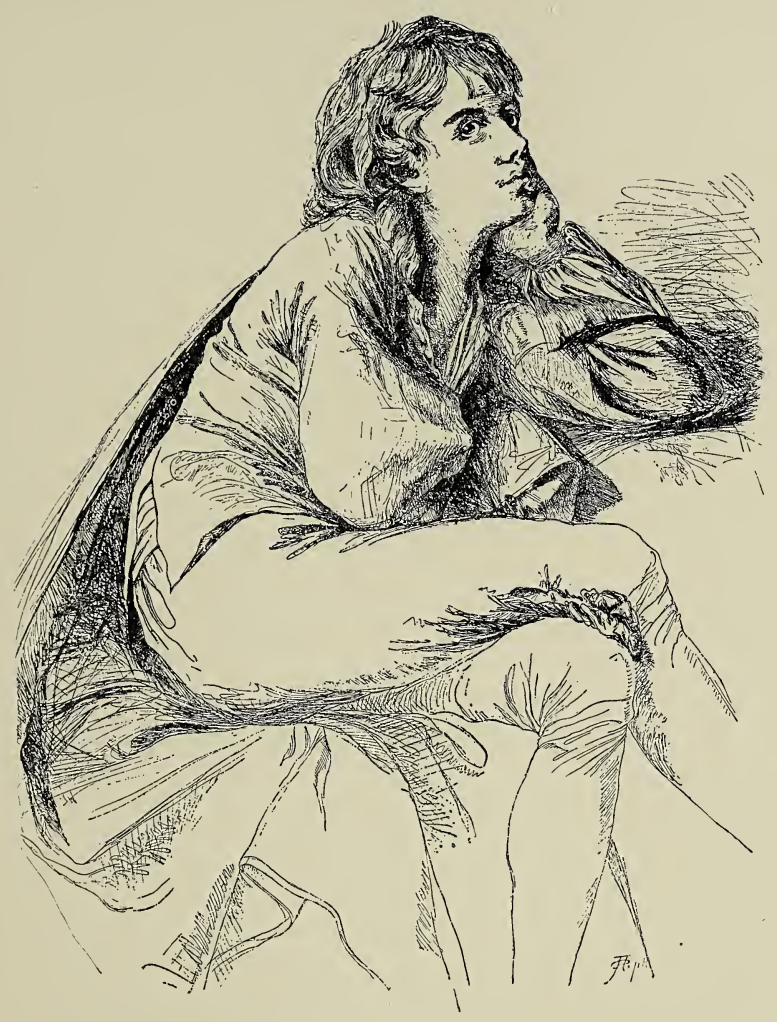

SEYMOUR HADE.

"THOMAS HADE, AFTER WRIGHT OF DERBY." 



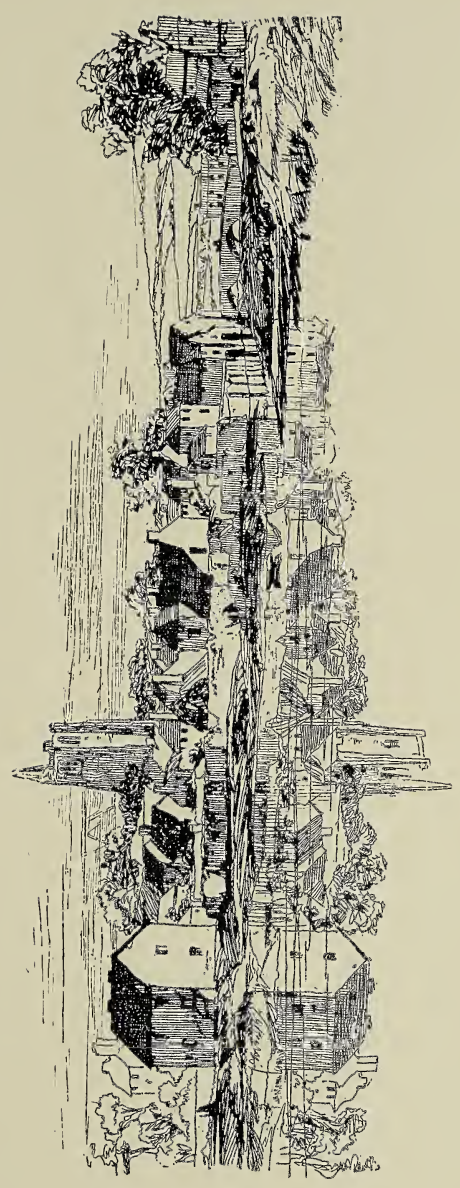

G

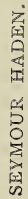



water, of the homely buildings of a little whitewashed town in Wales ("Kidwelly Town ").

A few years later, when the achievements of Haden had grown numerous, the intelligent French critic, Monsieur Philippe Burty (whom the revival of etching greatly interested), praised and chronicled them in the "Gazette des Beaux-Arts." There were fifty or sixty prints by that time. This was in 1864. And in 1865 and 1866, about thirty of them-including the minor but still attractive plates used as "head" or "tail-pieces"-were formally published in Paris, with a French text which consisted in part of an excellent analytical and didactic letter, written in the foreign tongue, by the artist to Monsieur Burty.

I864 and 1865 were years of great productiveness, and among educated lovers of Art, at home and in France, popularity, hitherto denied to the etcher-for Whistler was little appreciated and Méryon was starving-courted Haden with its blandishments, or threatened him with its dangers. Of the "Shere Mill Pond" Mr. Hamerton spoke in "Etching and Etchers" in terms of what I cannot but think was somewhat exaggerated praise. In 1870 , the large and impressive plate of "The Breaking up of the "Agamemnon " - " "large" I say ; not "huge," for " the huge plate is an offence" 
-put the coping-stone upon that edifice of Seymour Haden's celebrity to which the writings of Mr. Hamerton (in the now standard volume I have already referred to) had contributed an important storey. Mr. Hamerton, at that period, there can be little question, did not fully appreciate Mr. Whistler. I am not certain that he ever did. He already wrote of him-need I say?-with intelligence and interest, but his enthusiasm was reserved, so far as the moderns are concerned, for Méryon and for Haden.

Save for an exceptional activity in the year 1877-the year of the Dorsetshire drypoints and of the Spanish etchings-the productiveness of Seymour Haden, since r 869, began visibly to slacken. In I879 it stopped. The 185 etchings chronicled by Sir William Drake in "A Descriptive Catalogue of the Etched Work of Francis Seymour Haden" had all been executed; and soon afterwards-either during Seymour Haden's visit to America or during a visit of Mr. Keppel's to these shores-the veteran artist said to the New York printdealer: "I shall etch no more." I imagine Mr. Keppel's countenance of surprise and regret, and Seymour Haden's interested observation of it. But the incident was not over. The artist brought out his etchingneedle; looked at it; placed it gravely in 


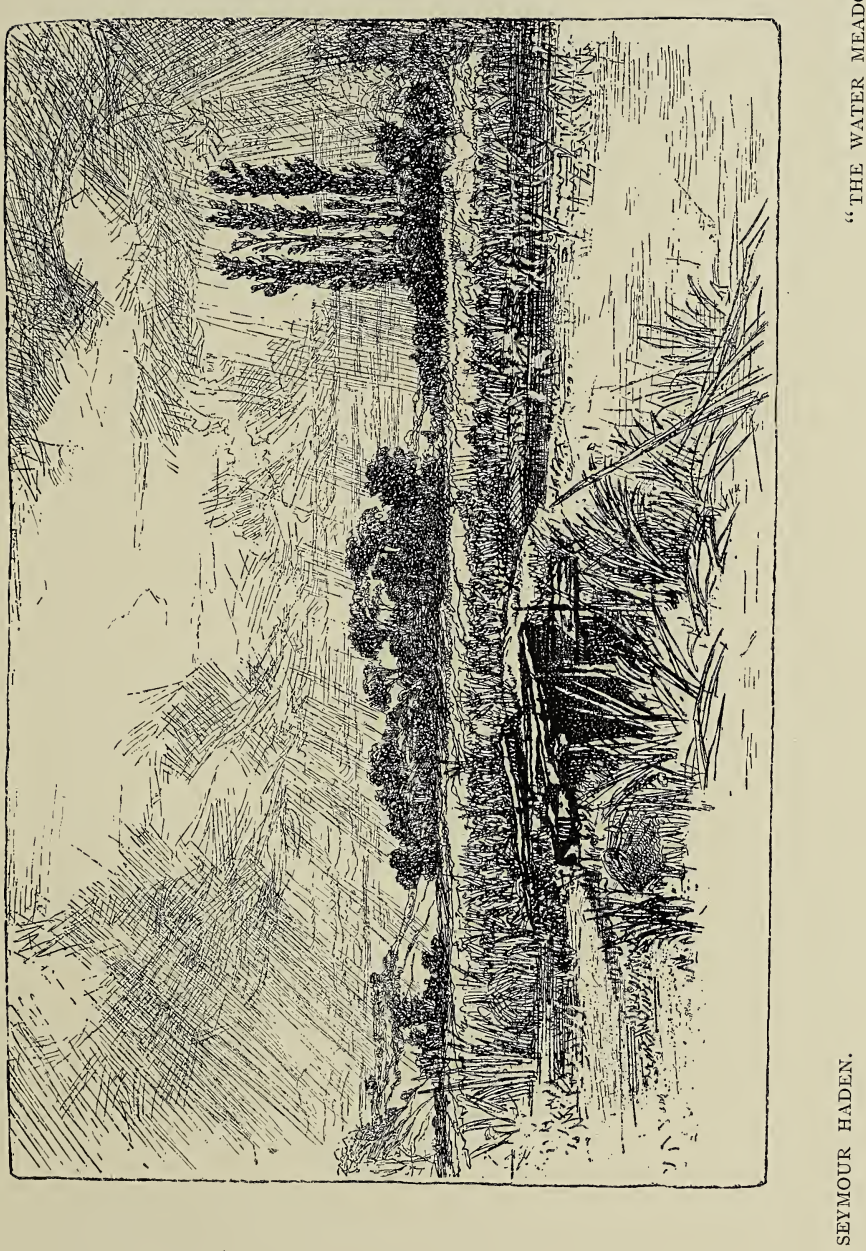




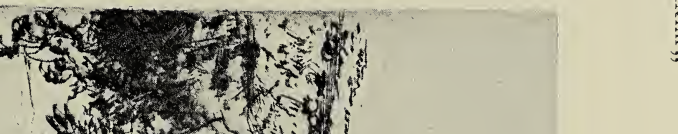

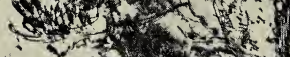
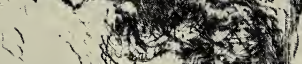

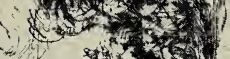

$\because 12 c^{2}$

14

y: $: 4016$

3)

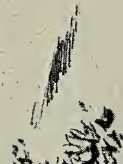

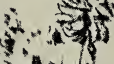

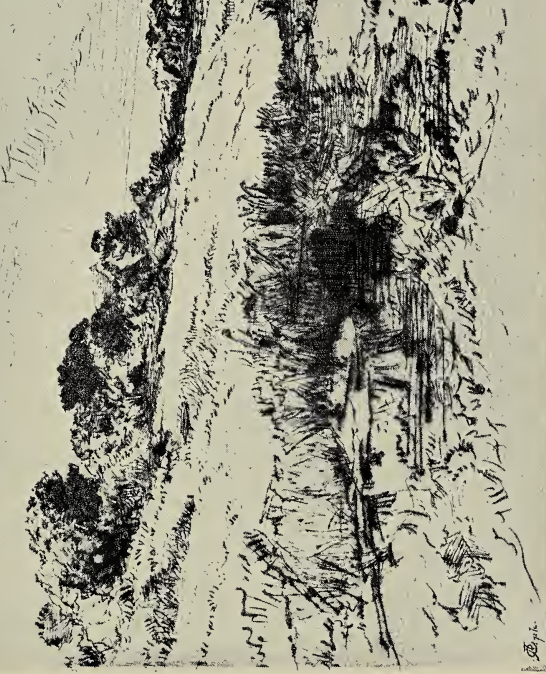

(a) 

Mr. Keppel's hands. It was presented to him as a sign that that which had been spoken would surely be fulfilled, and the etcher would etch no more. Like Madame Arnould-Plessis, like Macready, too, but like how few of his fellows in any department of public effort, this artist withdrew himself from productiveness before ever the quality of his production had visibly failed.

Perhaps I shall do well, in one or two last paragraphs about him, to name, for convenience sake, a few of Sir Seymour Haden's most excellent and most characteristic works-prints in which his vivid impression of the object or the scene before him has been most vividly or, it may be, subtly conveyed-prints, perhaps, which have his most distinguishing qualities of directness and vigour. The etchings of Seymour Haden are deliberately arrested at the stage of the frank sketch; but it is the sketch conceived nobly and executed with impulse. It is not the sketch upon the thumb-nail; it is not the memorandum that may be made upon a man's shirt-cuff at dinner-time, in the interval between the soup and the fish.

The tendency of his work, as time went on, was, as is usual, towards greater breadth; but, unless we are to compare only such a print as "Out of Study-Window," say (done in 1859), with only the most admirable 
dry-point, "Windmill Hill" (done in 1877), there is no greatly-marked contrast, no surprise; there is but a steady and slow and apparently inevitable development. This $I$ in part attribute to the fact that when Seymour Haden took up etching seriously in $185^{8}$, he was already middle-aged. He had lived for years in frequent intercourse with noble and accomplished Art; his view of Nature, and of the way of rendering her, or letting her inspire you, was large, and likely to be large, almost from the beginning. Yet, as time went on, there came, no doubt, an increasing love of the sense of spaciousness, of breadth, and of potent effect. The work was apt to become more dramatic and more moving. The hand asked the opportunity for the fuller exercise of its freedom.

"Sawley Abbey," etched in 1873, is an instance of this, and I am glad to mention it, not alone for its merits, but because, like a certain number of its fellows among the later work, it is etched on zinc-a risky substance, which succeeds admirably when it succeeds, and when it fails, as Sir Seymour tells me, fails very much. "Windmill Hill," "Nine--Barrow Down," "Wareham Bridge," and "The Little Boathouse," and, again, that "Grim Spain" which illustrates my "Four Masters of Etching," are the prints which I should most choose to possess 


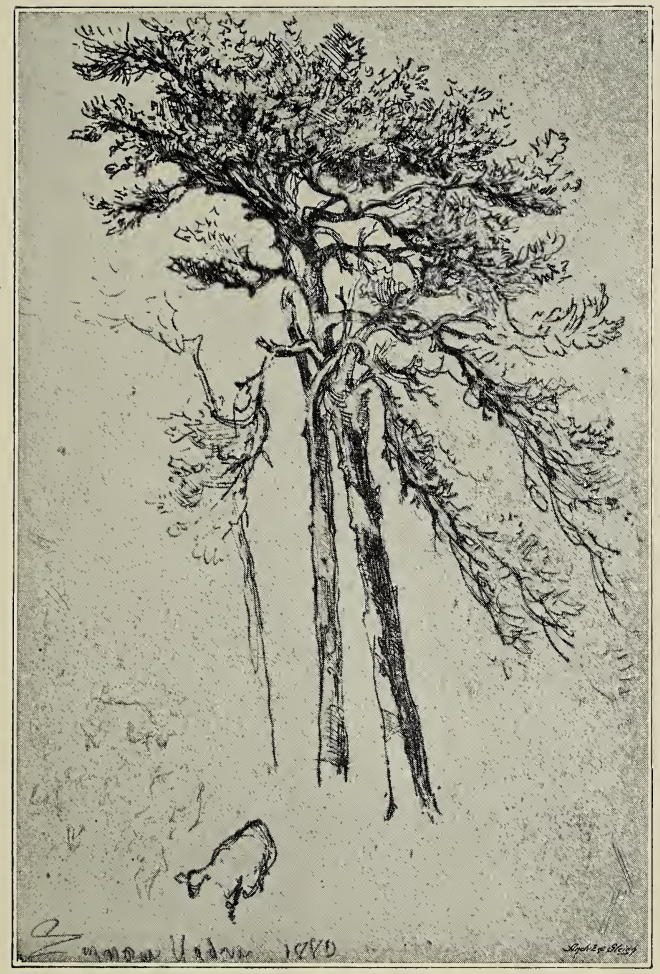

SEYMOUR HADEN.

"SCOTCH FIRS."

(The artist's last etching.) 

amongst those of Seymour Haden's later time; whilst, going back to the period of I864 and I865, "Sunset on the Thames" is at the same time popular and strong, and "Penton Hook" remarkable for its draughtsmanship of tree-trunk and stump. Yet earlier-for they belong to 1860 and I859- "Combe Bottom" is unsurpassed for siveetness and spontaneity, "Mytton Hall" for its full share of that element of Style which is never wholly absent from Seymour Haden's work, and "The Water Meadow" is to be studied and enjoyed as an extraordinarily happy transcript of a sudden rain-storm in the Hampshire lowlands, where poplars flourish and grass grows rank. 


\section{XI.}

\section{ALPHONSE LEGROS.}

J ORE than one of the great etchers 1 who must in fairness be treated with the British school are of foreign origin. Born at Dijon in 1837 , and trained chiefly in Paris-painter, of course, as well as etcher-Alphonse Legros came to London when he was quite a young man. He has been amongst us since 1863. It was in Paris, about I857, that he did his first etchings, and his surprising originality was declared from the beginning. The trivial, the accidental even, had no attractions for him. Even the quiet humour which one recognizes in his character, has no place in his work. Simple, serious, austere, highly refined, yet with curious tolerance of physical ugliness, and curious indifference to the beauty, at all events, of women, Monsieur Legros has conveyed to us, in his own leisurely and economical fashion, any time these thirty years, his vision of a world not ours, or 


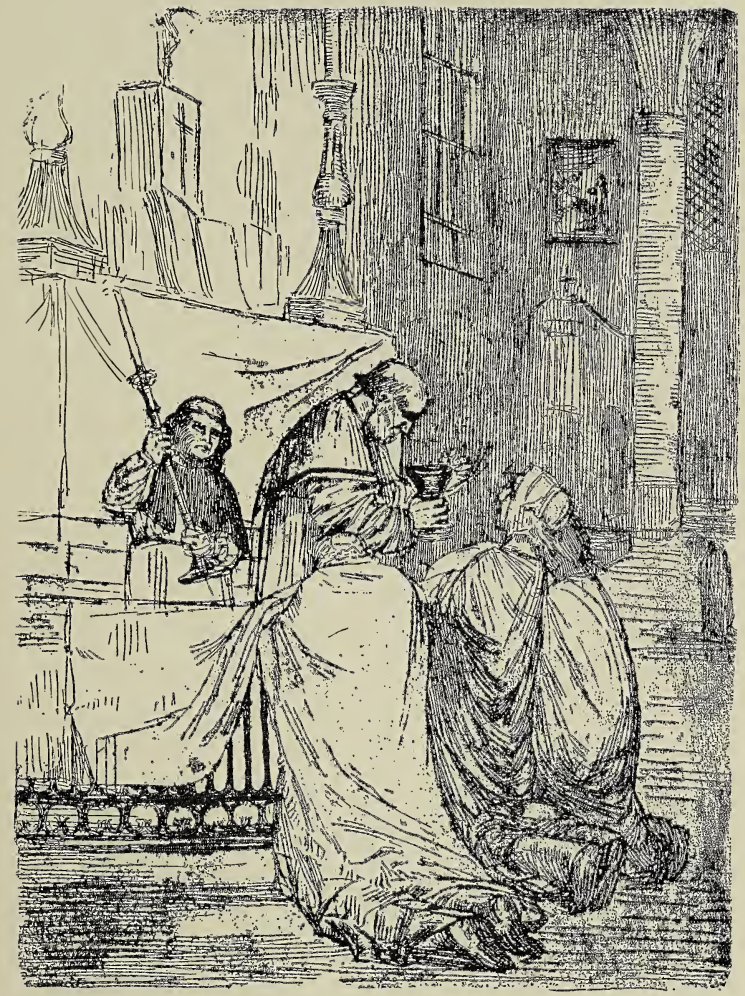

LEGROS.

"COMMUNION DANS L'ÉGLISE ST. MÉDARD, 

rather, very often, his vision of the deeper realities which underlie whatever mayattract us on the surface.

Legros has been concerned-and best of all concerned in etching - with many departments of Art. Like Mr. G. F. Watts, he has been fascinated, here and again, and very specially, by masculine intellect and character; masculine kindness, goodness, genius, energy. Of Mr. Watts himselfand fortunately in the medium of etching - he has made the happiest of all possible portraits, finding in the theme a gravity of manly beauty, a charm of approaching age, to which he has always been intensely sympathetic. Gambetta, too, and Sir Frederic Leighton, and Cardinal Manning-who, if he appealed to him at all, must have appealed to him on the side of austerity alone -have been the subjects of Legros's etched portraiture. To each portrait he has given, though in very different measures, according as the subject wanted it, a nobility and dignity supplied by his own art and temperament, and by a sense of Style nourished upon the study of the Renaissance and of Rembrandt. And, on the other hand, upon each selected model whom he has treated in those other etchings which are not confessedly portraiture, he has bestowed the grave veracity, the verisimilitude of the portrait. 
Hardly any of Legros's work is dated, and, as time has passed, the changes in his method have not been very marked, though it is hardly to the earliest etching that we must go for his most trained draughtsmanship and most accomplished technique. On the other hand, the early work has about it a sometimes savage earnestness, a rapid and immediate expressiveness, a weirdness also, which are immensely impressive. Poetic and pathetic is it besides, sometimes to the last degree. "Les Chantres Espagnols," for example, is the creation of a great artist : a most penetrating and pathetic study of physical and mental decay. It represents eight priestly singing men lifting up what hoarse and feeble voices they may be possessed of, in the hushed choir, by the uncertain light of torches, in the night's most mysterious and most ominous hour.

Several among the more fascinating of these somewhat early etchings and drypoints record the life of the priesthood. In its visible dignity, its true but limited camaraderie, in its monotony and quietude, in its magnificence of service and symbol, the life of the priest, and of those who serve in a great church, has impressed Legros profoundly, and he has etched these men-one now reading a lesson, one waiting now with folded hands, one meditative, one observant, and now one offering up the 


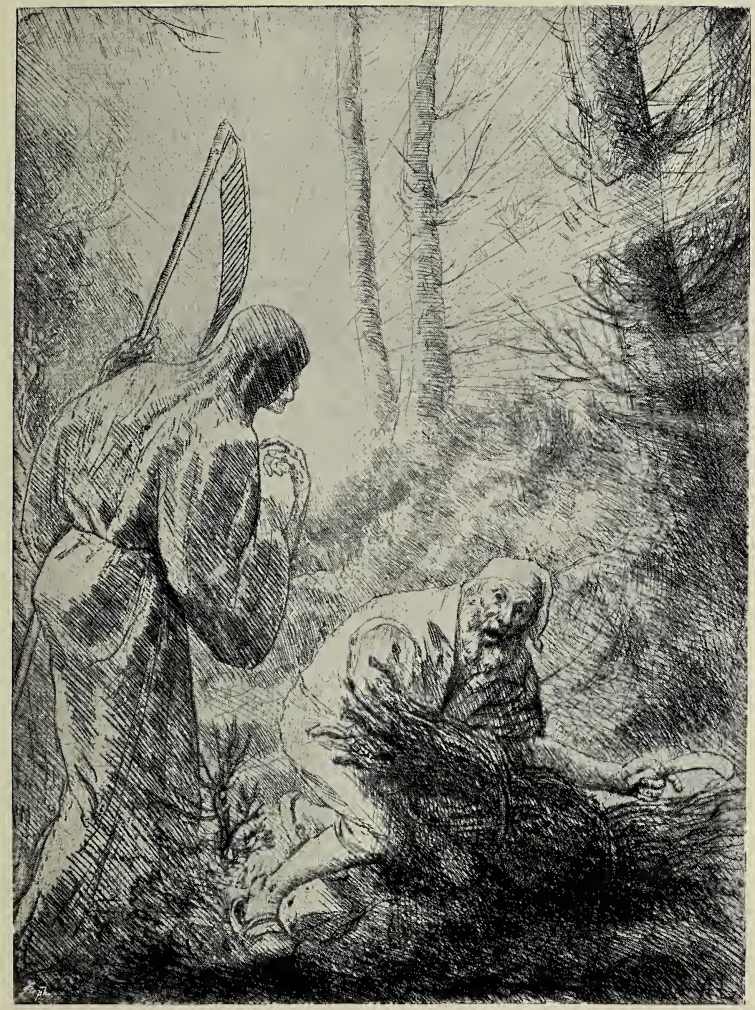

LEGROS.

"LA MORT ET LA BÛCHERON." 

Host, and now another bending over the violoncello with slow movement of the hand that holds the bow. Dignity and ignorance, pomp and power, weariness, senility, decay, and almost squalor-nothing has escaped him. In Literature, only a Balzac could have done equal justice to that which attracts, and to that which must needs repel.

Realist, but always poet, in his treatment of these themes-and in the treatment of such a dramatic plate as "L'Incendie," such a nobly imaginative plate as "La Mort et le Bûcheron"--Legros, when he betakes himself to landscape, is realist no longer, or, rather, his realism here is shown only in his contentment with the homely scene, the most everyday material. Generally, one's impression of his landscape is that it is built to some extent upon the memories of his youth ; that, since then, a little observation has gone a long way-that he has cared to dream and fancy rather than to actually notice. Here and there, in his etchings, one may be reminded of the uplands around Dijon, or of the chalk hills of the Boulognais, with its wide fields and haystacks, its gaunt outhouses - a land which rumours of "high farming" have never reached. As the railway train swept under the hillside, Legros, one thinks, may have profited by a glance from the windows. And out of the glance, and out of the memory, and out of the 
artist's genuine sympathy with humble and monotonous days, there has grown a homely poem.

With Mr. Whistler, on the rare occasions on which he has treated it in his mature art (in the rare "Dam Wood" especially), Landscape becomes Decoration. With Sir Seymour Haden, landscape is a matter that must be energetically observed. Swift, skilful memoranda are taken of it-memoranda which are not the less scientific because they may be dramatic besides. With Legros, the landscape must submit to change, to simplification, to abstraction, generalization even, in the processes of his mind; and the picture which his hand fashions--the hand with reverie behind it-is one which travel will help no one to encounter, and experience help no one to realize. Yet it has its own value.

Before I leave this deeply interesting and so original artist, I will add that in the "Catalogue Raisonné de l'Euvre gravé et lithographié d'Alphonse Legros," compiled by Messieurs Thibaudeau and Poulet-Malassis in 1877 , there are chronicled I68 pieces, but that, writing to me ten years later, M. Thibaudeau was able to tell of nearly ninety additions to the list. Since then the number has been yet further extended, for Legros, to this day, has not ceased to etch. 


\section{XII. \\ WILLIAM STRANG.}

PROFESSOR, during something like a score of years, at the Slade School in London, Legros had then a dominating influence upon many amiable followers who will hardly hereafter be heard of, and upon two or three clever people with a future in Art. Among these latter-if, for our present purpose, we disregard men who are painters exclusively, like Tuke and Gotch-the most conspicuous are William Strang and Charles Holroyd. Strang is the senior. He has thus far, naturally, been much the most prolific. He is also the most technically accomplished, and, more than any younger etcher of the day -almost as much, indeed, as Monsieur Legros- - he has shown himself possessed of the vital gift of imagination. Like Legros, he has looked immensely at Old Masters -at the Italian Primitives and at Rembrandt-and has seen Nature in great measure through their eyes, and this as 
much when Humanity as when Landscape has been the object of his gaze. In Strang's case, too, to these accepted and avowed Old Masters, there has come to be added another Old Master-I mean, Alphonse Legros.

Strang is a Scotsman. That devotion to the weirdness and the uncanny, which is a note of the full Celtic temperament, is shown amazingly in his selection of subject; he is, perhaps, most of all contented with himself when he sets himself to illustrate a ballad of the supernatural, written in a dialect into the last recesses of which I-who love best the English tongue-lack, I confess, the energy to penetrate. His imagination, however, is far from being exercised alone on these themes of the supernatural. It is occupied, not seldom, with as great a power, upon modern incidents treated with quaintness and intensity - the meditations of a jury, the expositions of a preacher, the rescue of the drowned from some dark river, the illbred hysteria of the Salvation Army. In portraiture, while it is yet visible, and even valuable, it is controlled sometimes by sense of Style, and then we have, as in the almost Vandyke-like portraits of Mr. Sichel, and of Jan Strang-the nearest approach which Mr. Strang suffers himself to make to the wide domain of beauty. His customary indifference to charm of form, to charm of 


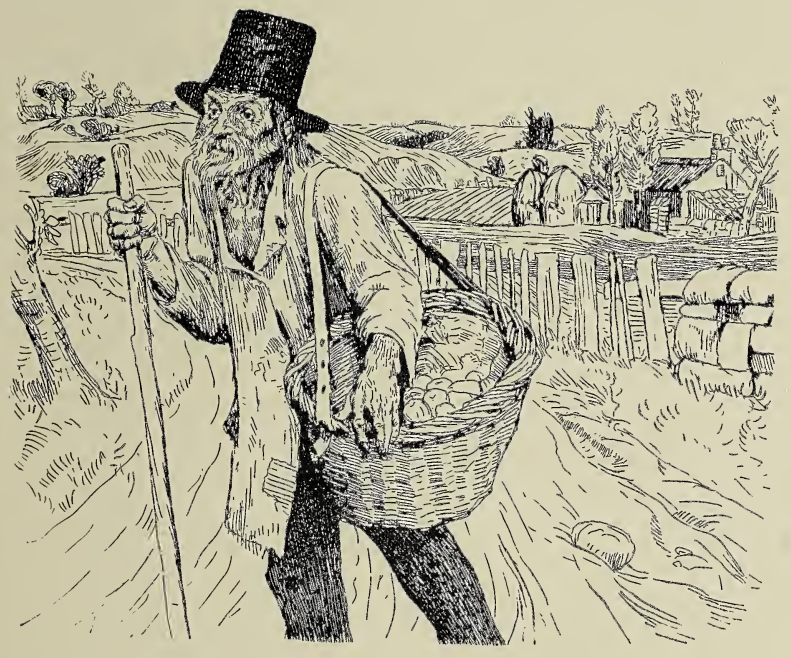

STRANG。

"THE POTATO BASKET." 



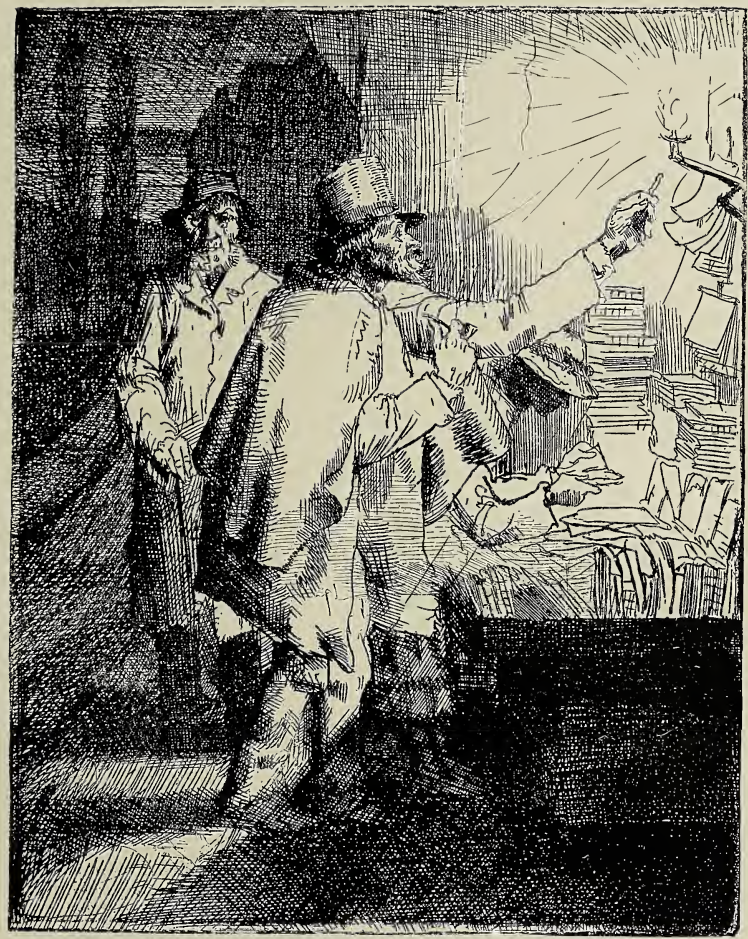

WILLIAM STRANG.

"THF BOOKSTALL." 



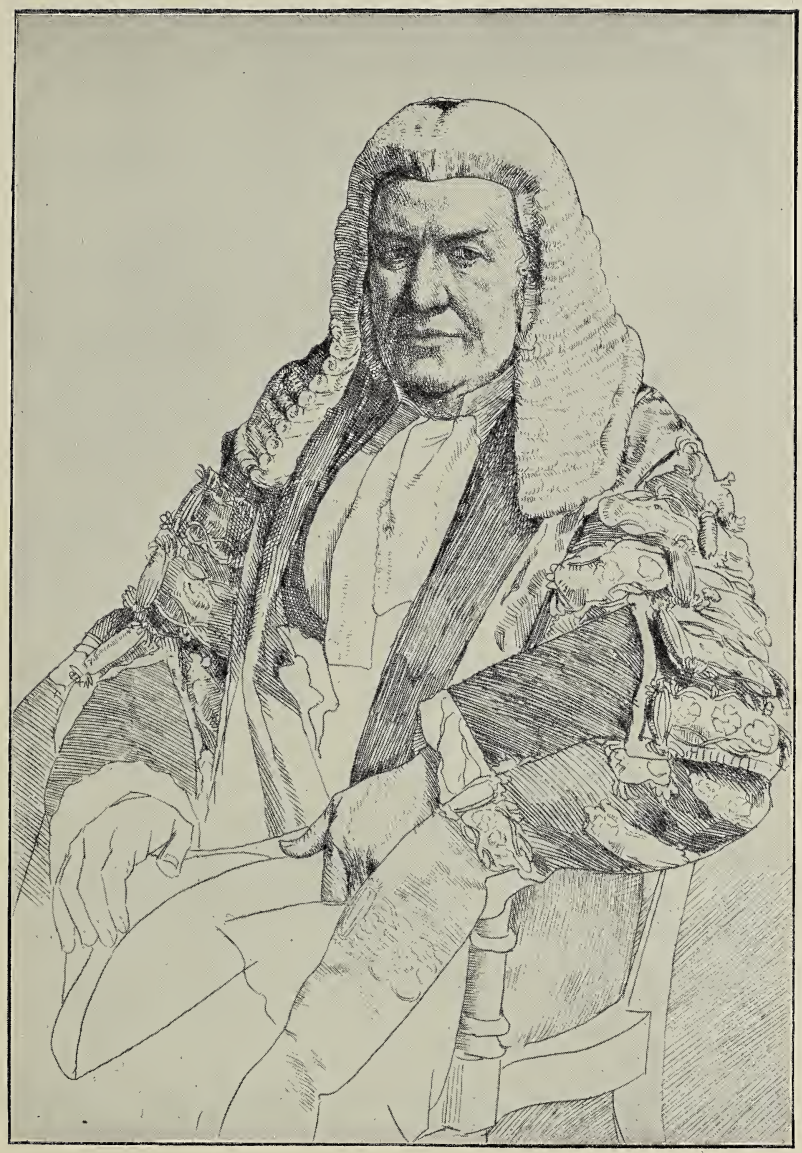

WILLIAM STRANG. "JUSTICE LINDLEY." 

expression, to that which is agreeable and comely, to that which the natural man would voluntarily look upon, is yet more marked-a hundred times more markedthan Mr. Legros's. Grace, elegance, personal distinction, the freshness of youth, the winsomeness of girlhood, the acceptability of the English upper classes-these things are far from him: he wots not of them, or but rarely. He likes poor folk, enjoys the well-worn clothes, the story of the poor folk's work and poor folk's trouble. For that I do not blame him. But, like Ostade and Brouwer, he likes the cottager best when he is stunted, and is most interested in him when he is gnarled.

For all the absence-an absence frequent, not continuous-of local colour, the scenes Mr. Strang depicts arrest you. You remember them because he has himself remembered that which was most important in the making of them. Essentials have not escaped him. The "realism" he has attained has been at least something much deeper than that which prides itself on the correct portrayal of the obvious. In great themes and little themes he has been alike vivid. There may be something that is squalid and something that is ignoble in "The Last Supper" as he can conceive it ; but, at all events, a genuine human emotion is not banished from the scene. He is Von 
Uhde-like in that. And here and there, in brief suggestive studies of contemporary existence, an imaginative light is flashed upon the page, a touch of romance suggested, as where, in the curious little etching of a Bohemian wayfarer-a someone who has lost caste probably, whose pence and whose friends are few-lighting his pipe at a flaring gas-jet over some street bookstall on a Saturday night, you feel that for a moment there has sprung into your vision a fellowcreature with a history, whose mysteriousness you will not solve. Out of the darkness he has emerged for an instant, and into it he returns again.

This very remarkable artist has already executed not less than two hundred and fifty etchings. 

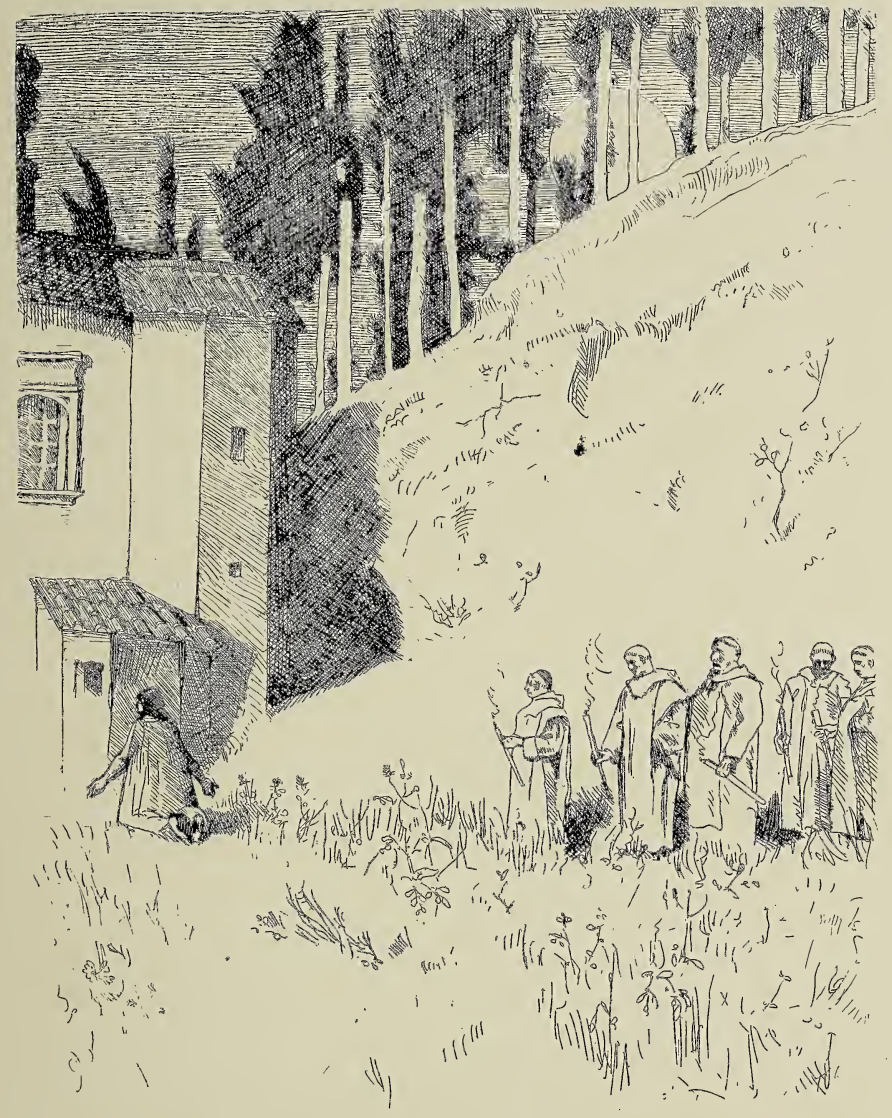

CHARLES HOLROYD.

"MIDNIGHT MASS." 



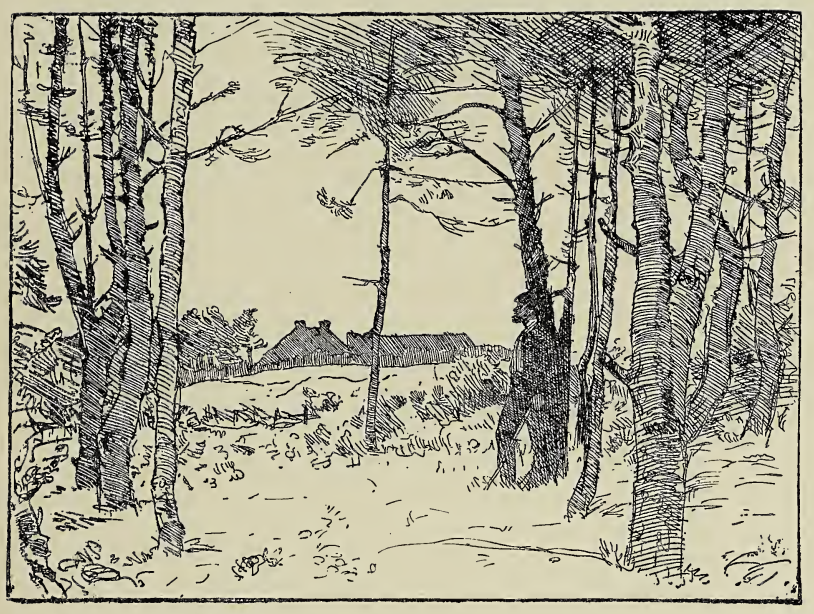





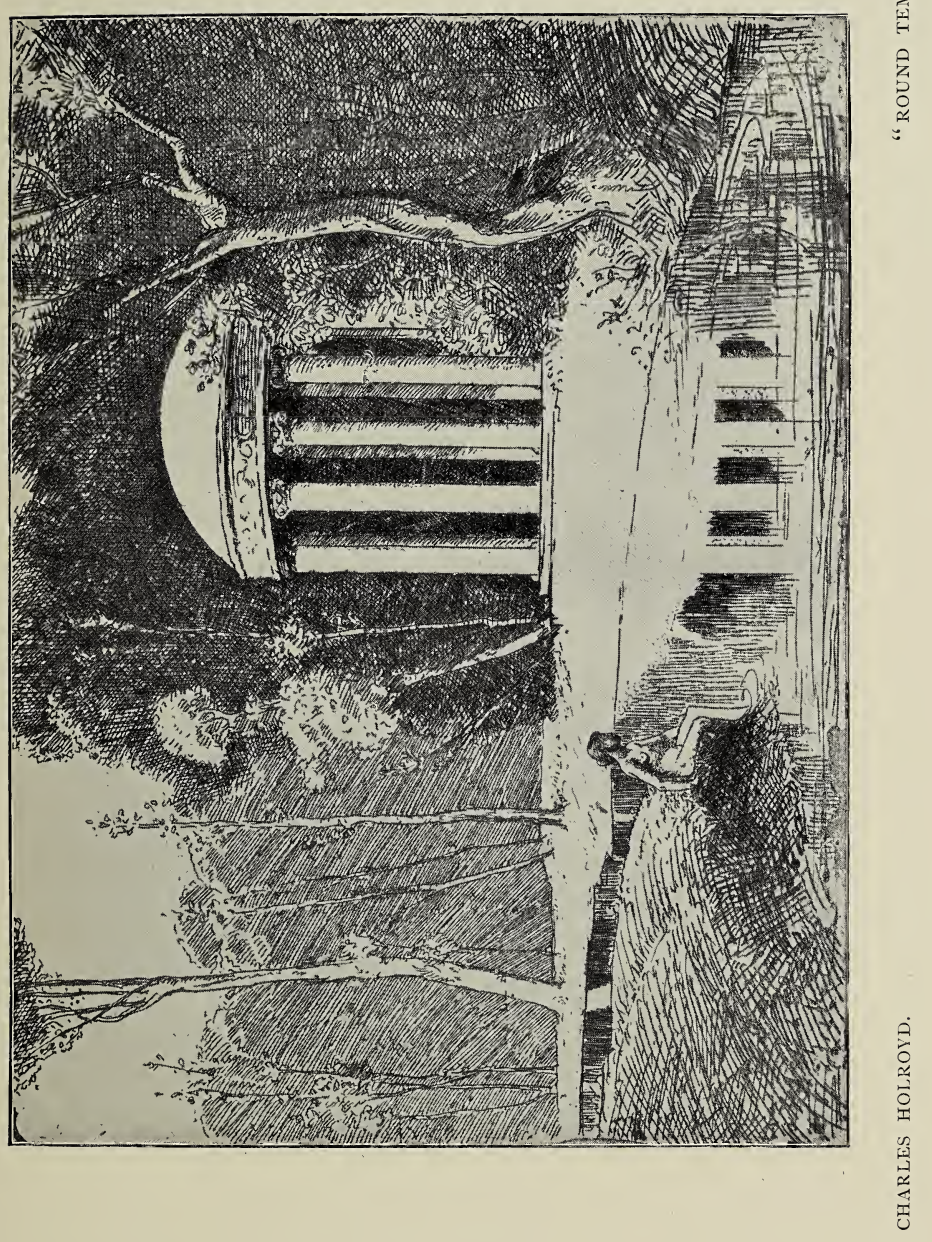





\section{XIII.}

\section{CHARLES HOLROYD.}

RESIDENCE of two or three years
in Italy - where he enjoyed the Slade School Travelling Studentship-has vied with the tuition of Mr. Legros in influencing that more than promising etcher, Mr. Charles Holroyd. A sense of dignity and Style, and, with this, some direct personal inspiration, lift Mr. Holroyd's work entirely above the level of the commonplace and the ordinary. In sense of line, indeed, he not seldom makes approach to the classic. He has affinity with Claude and with George Barret.

Several of the best of Mr. Holroyd's not yet very numerous prints-each one of which is well-considered, thorough and serious work -deal worthily, truly that is, and yet imaginatively, with the lives of ecclesiastics, among the cypresses and olive woods and pine-trees of Monte Oliveto, and in the gaunt and spacious chambers of the remote and hillside monastery, in which Mr. Holroyd, 
with his love of Italy and of its graver life, was sometime minded to abide. Thus, in the Monte Oliveto series, we have the sombre yet pictorial incident of "Midnight Mass," and, again, the "Ladies' Guesthouse," with its Tiepolo-like charm.

The homeliness of subject in his "Farm behind Scarborough" does not forbid the display of certain of Mr. Holroyd's virtues. Yet perhaps more characteristic is the "Round Temple," or that "study of line" suggested by the noble and free beauty of the Borghese Gardens. "Round Temple" is the fuller, the more realized. "Borghese Gardens" consciously and inevitably abandons much that is wont to attract, but it retains the thing for which it has existed -dignified and expressive rhythm of line. And this justifies it, and permits it to omit much, and only to exquisitely hint at the thing it does not actually convey. 


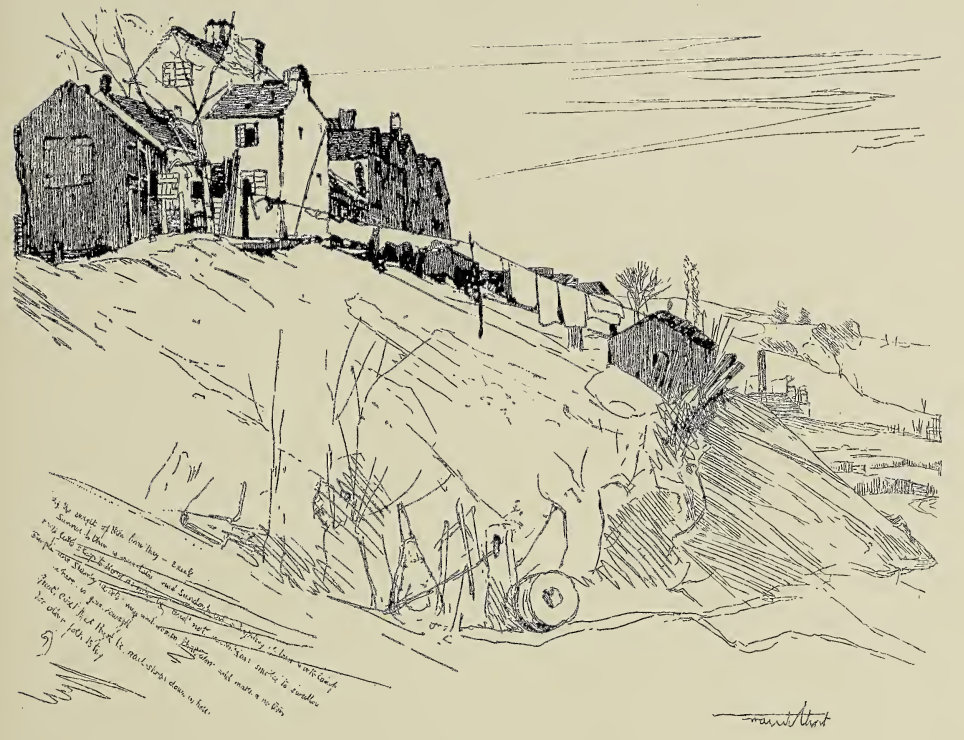

FRANK SHORT.

"WROUGHT NAILS" 



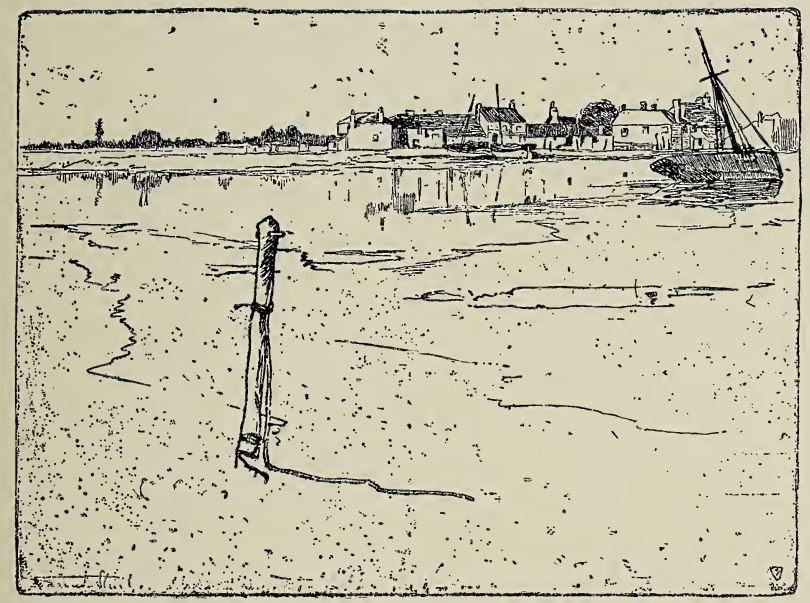

FRANK SHORT. 



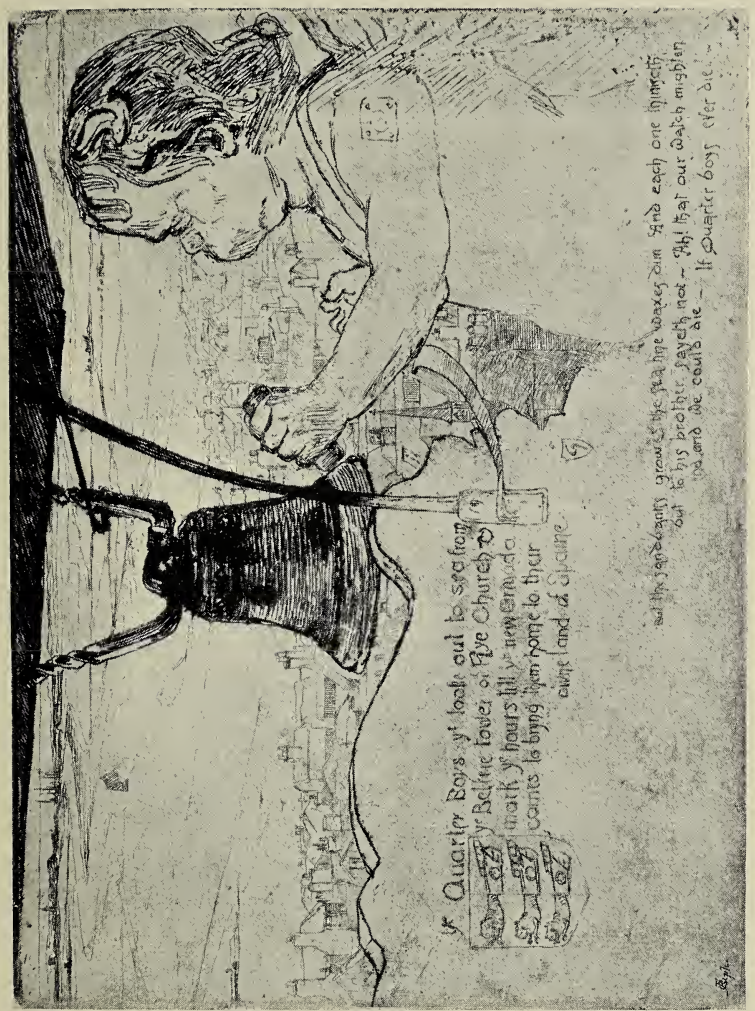

足

瀮 



\section{XIV.}

\section{FRANK SHORT.}

MONGST the original etchers remain-
ing to be discussed I place Frank
Short almost at the top of the tree. Some people will say that Short's true place would be with copyists or interpreters rather; but that is only because they do not know his original work - the very limited issue of his original plates having withheld from them a publicity won already indeed by many of his brilliant interpretations of the pictures or the drawings of long-accepted artists. No one-not even Mr. Wehrschmidt or Mr. Gerald Robinson-has done as much as Frank Short for the modern revival of mezzotint. It is more perhaps by mezzotint than by any other medium that $\mathrm{Mr}$. Short has effected his delightful translations of Turner, of Constable, of Dewint, and of Watts. But if not one of these things existed--if he had never wrought those exquisite interpretations, for example, of a sketch by Constable, belonging to Mr. Henry Vaughan, and of a Dewint drawing, 
"A Road in Yorkshire"-if nothing of this work whatever had been done by Mr. Short, then would he still have cause to be remembered and valued by reason of the beauty and the technical virtues of his original prints.

Frank Short's original prints are, indeed, of all the greater merit because, just as Mr. Whistler himself, he has disregarded in them, from beginning to end, the taste of the everyday public. This delicate array of exquisite etching-very little of it merely tentative; most of it of complete accomplishment, if of limited aim-has been called into being, as Mozart said of his "Don Giovanni," "for himself and two friends." The "two friends" must be taken-one need hardly protest-cum grano salis; they represent the rare connoisseur, the infrequent person who enjoys and understands.

Two classes of subjects have hitherto to a great extent engrossed Mr. Frank Short in his original work, and to these there must now be added a third; for within the last year or so, following in the wake of his friend Mr. C. J. Watson, he has visited the land of Rembrandt, and has done charmingly suggestive and vivacious sketches of quaint town and long-stretched shore.

But the two classes of subject with which one has been wont to identify him are subjects of the English coast and of the English 
manufacturing districts; and, in a certain sense, even these two subjects are one, and this one theme may be described-not too imaginatively, I think, if we look into the heart of the matter-as the complete acceptance of all that is considered unpicturesque in modern life: in the manufacturing districts, the factory chimneys, the stunted, smoke-dried trees, the heavy skies, the dreary level water, along which barges make their monotonous way (see the interesting dry-point, "Wintry Blast on the Stourbridge Canal "), and, on the English coast, the massive stone pier, the harbour muddy at low tide, the tug, the sheds, the warehouses, or it may be perhaps the wooden fences that protect and preserve the foreshore-the beauty of the whole, which is unquestionable, being obtained by a particularly subtle arrangement of line, a perfect sense of proportion, a perfect delicacy of handling: Coarser people, of more ordinary vision, addressing themselves, as by a parti pris, to these themes, have treated them with brutality. But, on these themes, it is the distinction of the treatment of Mr. Short that in rendering them with fidelity and patience-even with love - he yet somehow, in the brief phrase of Robert Browning-

"Put colour, poetising." 
Yes, a certain measure of poetry must certainly be claimed not only for the "Evening, Bosham" and the "Sleeping till the Flood," but for the "Stourbridge Canal," which has been mentioned already, and for the print of "Rye's Long Pier"this is called indeed, poetically enough in its suggestiveness, "Low Tide and the Evening Star"-and for the curiously clever little plate, "Wrought Nails," a scene of the Black Country, which shows the sheds of the workers, and little trees untended and decaying, and a bit of waste land, ragged and dreary, with nothing of Nature left, but only the evidence of men's grimy labours, of their hard, monotonous life. And, though up to the present, or until very lately, the field of Mr. Short's own observation of the world may seem to have been limited, it is plain to any qualified student of his prints that he has gained the effects he wanted by a fine sketcher's economy of means, by a thorough capacity of draughtsmanship, much sense of design, and a very exceptional control over the technical resources of the etcher's art. 


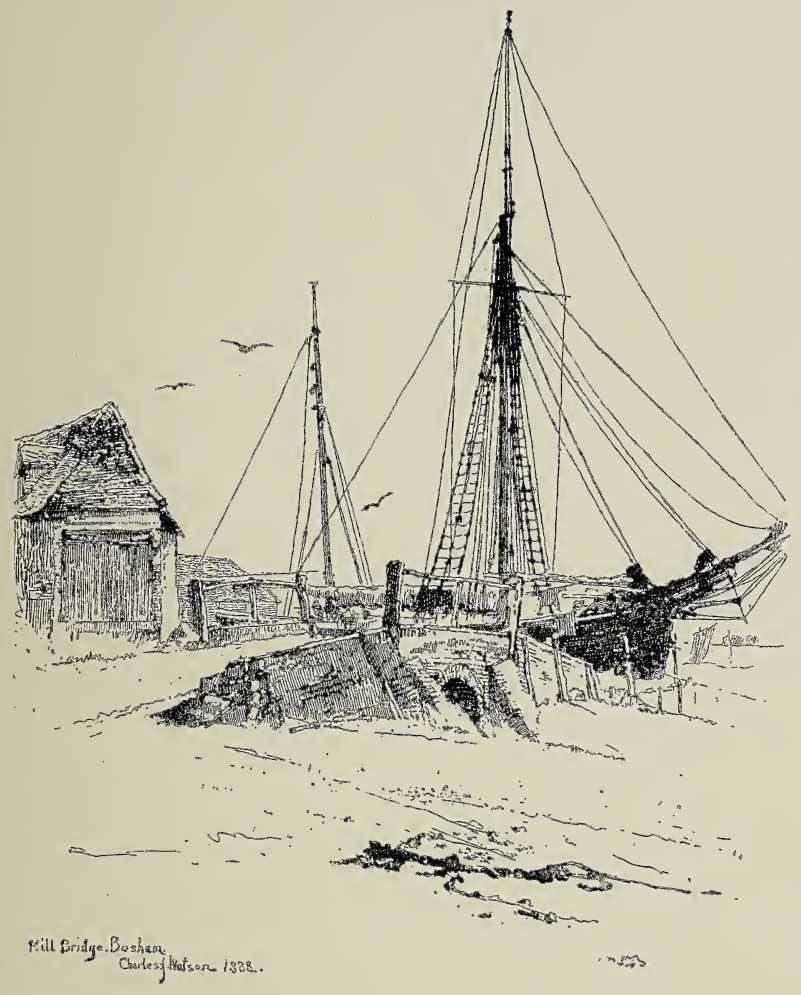

C. J. WATSON.

"MILL BRIDGE, BOSHAM." 



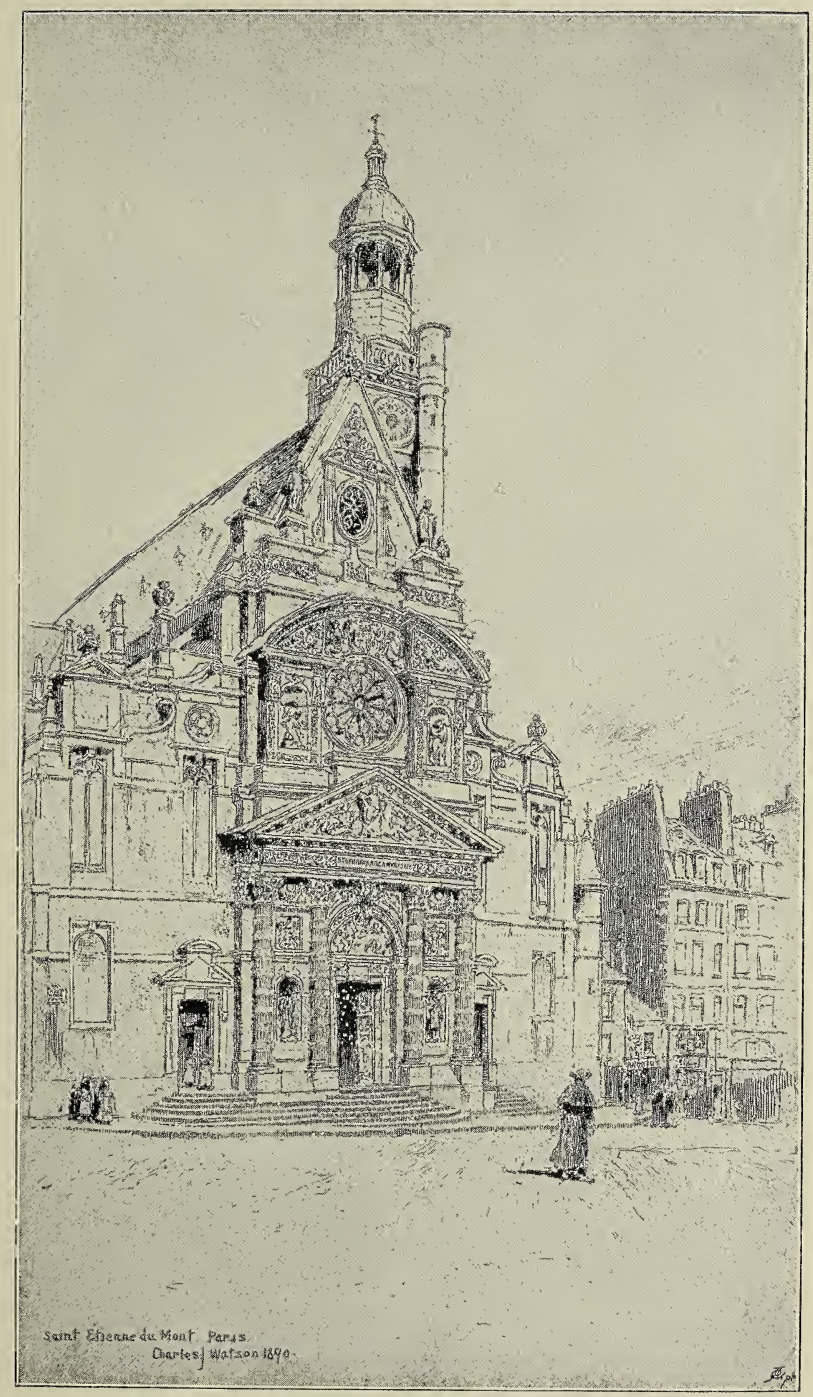
C. J. WATSON.

"ST. ETIENNE-DU-MONT." 



\section{XV.}

\section{J. WATSON.}

THE work of Mr. C. J. Watson is nearly

1 always absolutely sturdy and sterling. It has tended, too, to become delicate; and when one compares it with Mr. Short's, very likely the only thing which puts it at an obvious disadvantage is that (though one can hardly explain the matter) it has an air of being less personal. That, I admit, is no small affair. Judging from the work alone-and no one would desire to make the comparison except from the work only -one would say, "Here is a strong and capable hand, stirred to expression by a nature much less sensitive than that which reveals itself in the etched lyrics of Frank Short." Mr. Short records facts-not great and doleful dreams, like Mr. Strang or Mr. Legros-but he records facts poetically. More absolutely matter-of-fact is Mr. Watson, who (I am speaking of him, of course, apart from his agreeable gift of colour) so far portrays things realistically that the 
personal, the individual, is comparatively absent, and his art can hardly be described in the phrase which does define Art generally - Nature beheld "à travers d'un tempérament."

But Mr. Watson, who has long been interesting, has of late years become within certain limits a first-rate craftsman, albeit still a little wanting in vivacity. It may be that his individuality-such individuality as he possesses-has to be sought for in the soundness of his technique, and in the ripe judgment which he shows in treating subjects which at least are true etcher's subjects. Practising his art during early manhood in Norwich, and being himself, with his sturdy realism, as it were, a last echo of that "Norwich School" in which only Cotman was essentially and primarily poet-and Cotman could be realistic, too-Mr. Watson came, a few years since, to London, and here he has developed his powers a stage further, there is no doubt; producing, in the first instance-since his residence in town, with its wider associations and its greater activities-plates admirable for directness and certainty, such as "The Mill Bridge, Bosham," and then the "Chartres," its gabled and dilapidated houses, rather; the back of Chartres-Chartres on the wrong side-and then the "St. Etienne du Mont," its west front-that is, the front of one of the most 
curious and characteristic of the churches of Paris-and then the "Ponte del Cavallo," a refined, if scarcely individual vision of Venice.

Some greater delicacy and flexibility of method than were before possessed, or than were even desirable, perhaps, for the subjects to which Mr. Watson in his earlier days addressed himself, are evident in the "Chartres;" but they are yet more marked in the "St. Etienne" etching, which no true lover, no properly equipped student, of the achievements of the great original aquafortists will be able to examine without some thought of the wonderful plate of Méryon which bears the same title. Of the relative correctness of the two presentations-not, in my opinion, an all-important, though still an interesting matter-I will say nothing, or at least very little; possibly it was Watson who had looked the hardest at the actual façade of which it was his one business to convey the impression. Still, the immense solidity of Méryon's etching gives it a realism as much its own as is all the wealth of its poetry. The very simplification of the facts must have been deliberate, and it accomplished its end. It would be ridiculous to suggest that a draughtsman of architecture so patient and thorough as Méryon, could not have set forth each detail, as well as the general 
character, had it been his aim. He had other aims, and this detail accordingly had to be at times subordinated; for him there was not the church alone, but the College de Montaigu and the corner of the Panthéon, and the weird shadows and the passing women, and the dark mystery of the Paris street. In a word, there was his genius and his message-fancy or fantasy. For Mr. Watson there was "land, the solid and safe," as Mr. Browning moralizes; the solid earth, or what the architect had put therenothing else. And what the architect had put there Mr. Watson noticed-portrayed it with strength-portrayed it, too, as afterwards the "Ponte del Cavallo," with perhaps unwonted flexibility.

In simpler subjects than the "St. Etienne du Mont" Mr. Watson shows as well as, or better, than there, a quality very characteristic of the truest of modern etchers-of Mr. Whistler and Mr. Short particularlyI mean, in what is more or less architectural draughtsmanship, after all, an enjoyment of the evidences of construction. Very likely it may be said that that is a quality belonging to him as a good draughtsman, whether, at the moment etching happens to be, or happens not to be, the medium of his work. I think not. There is something in the etched line that reveals especially the presence of this enjoyment-that calls for the certain display of it. 


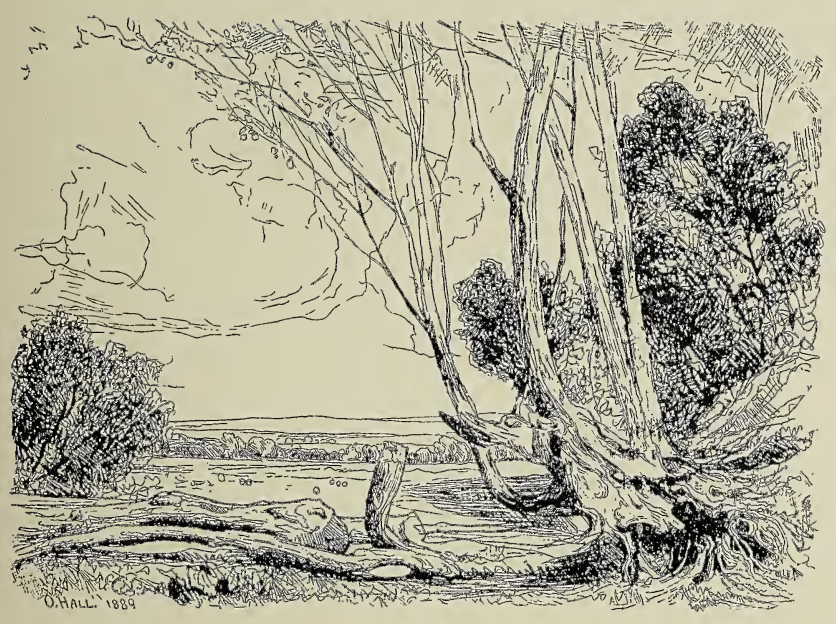

OLIVER HALL.

LANDSCAPE WITH TREES." 



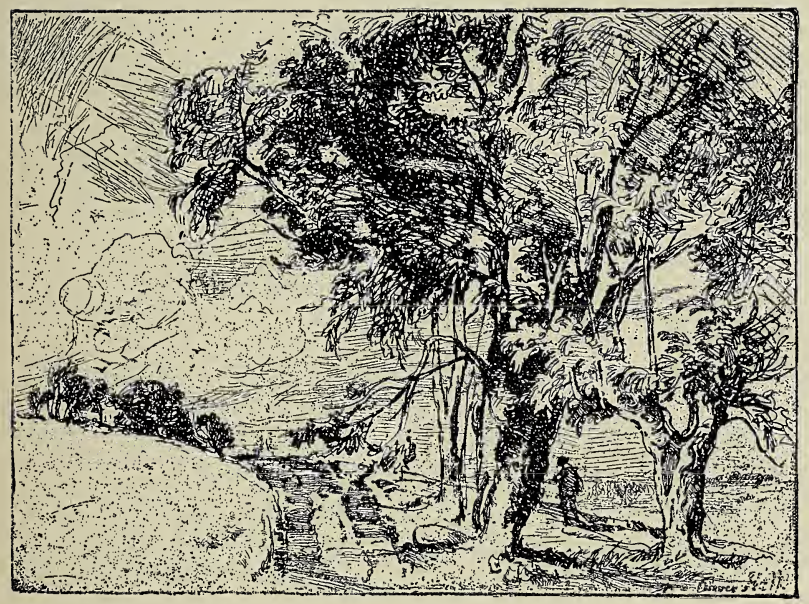

OLIVER HALL.

"ROADSIDE TREES." 



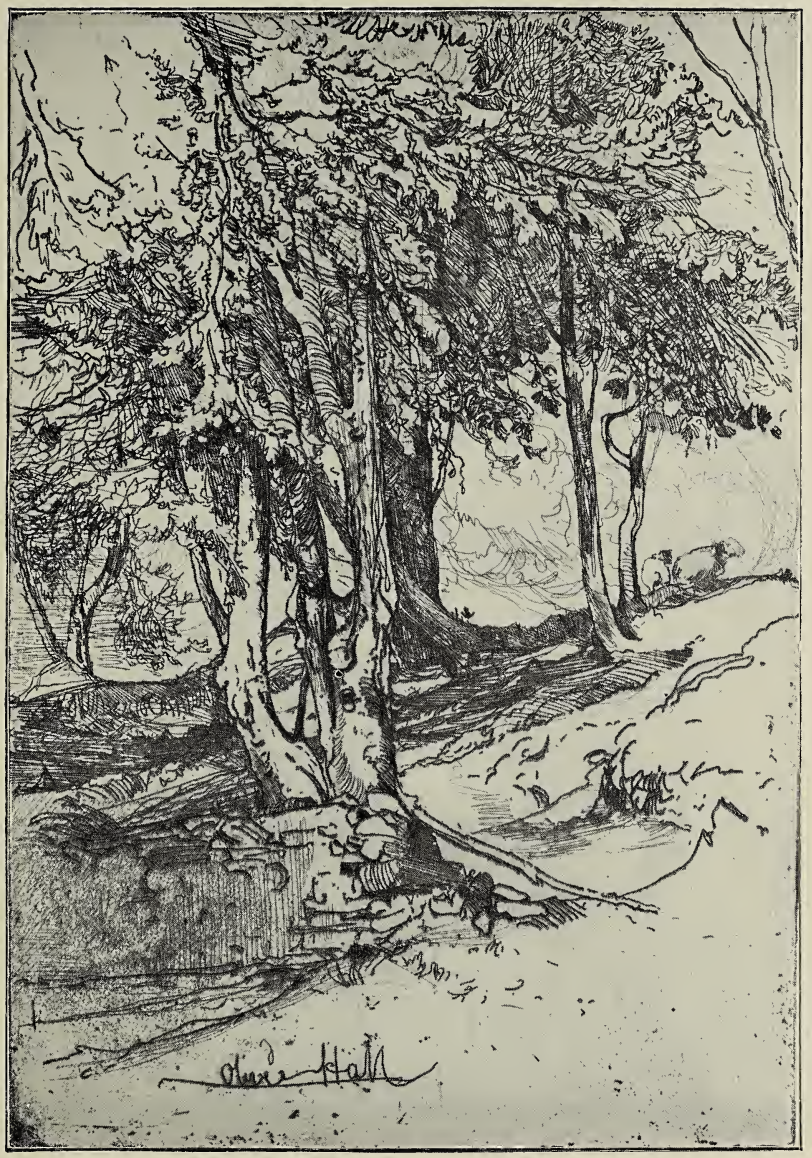

OLIVER HALL.

"TREES ON THE HILL-SIDE." 



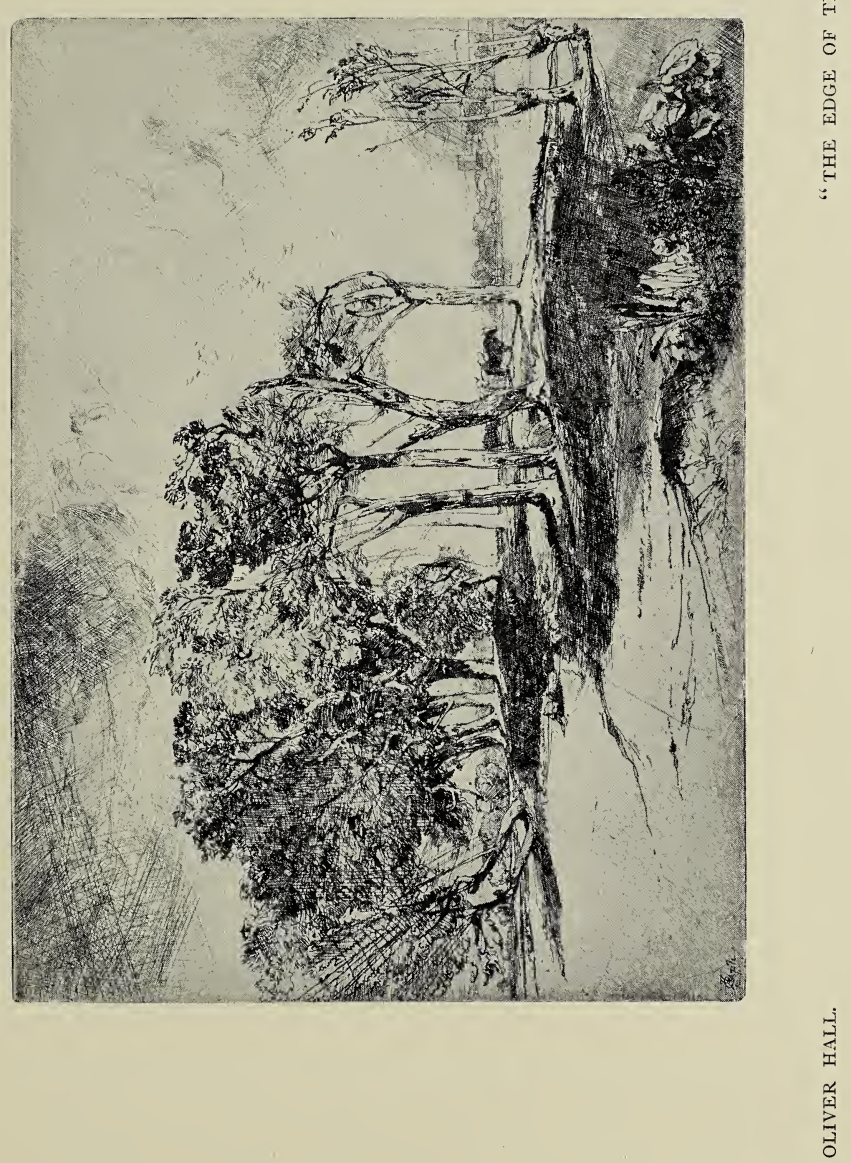





\section{XVI.}

\section{OLIVER HALL.}

IR. OLIVER HALL, a young and, 1 until lately, a comparatively littleknown but a distinctly interesting and strongly gifted etcher (who paints; he tells me, a good deal in water-colour), has next to be spoken of; and if his work has one characteristic more than another-though grace and freedom are its characteristics too-the one that is most its own is the continual evidence his plates afford of his enjoyment of growth and building up-his pleasure in the traces of the way by which the object before him became the object that it is. Mr. Hall's object is more likely to be a tree than a church. Architecture he does not attack, and his rare figures are but the figures of the landscape-painter. He labours amongst sylvan and amongst pastoral scenes that are not strikingly picturesque; and in method, as well as often in theme, he suggests Seymour Haden.

Mr. Hall has not yet wrought very many 
plates; they number, it may be, two score. $\mathrm{He}$ is not, in his work, always faultless, and perhaps he is not thus far very varied. But he is in the right track, and has shown no disposition to leave it. He has done beautiful things-the "Coniston Hall" one of the finest of them. He is a vigorous, frank, free sketcher, often sketching "effects," as well as forms that vanish less quickly; and, in the realm of effects, the very spirited etching, "A Windy Day," is perhaps the best of that which he has done. It is a scene on Angerton Moss, a stretch of open country rising to the right; the scattered trees and clustered farm buildings on the horizon line; and they are wind-swept, and wind is in the sky. 


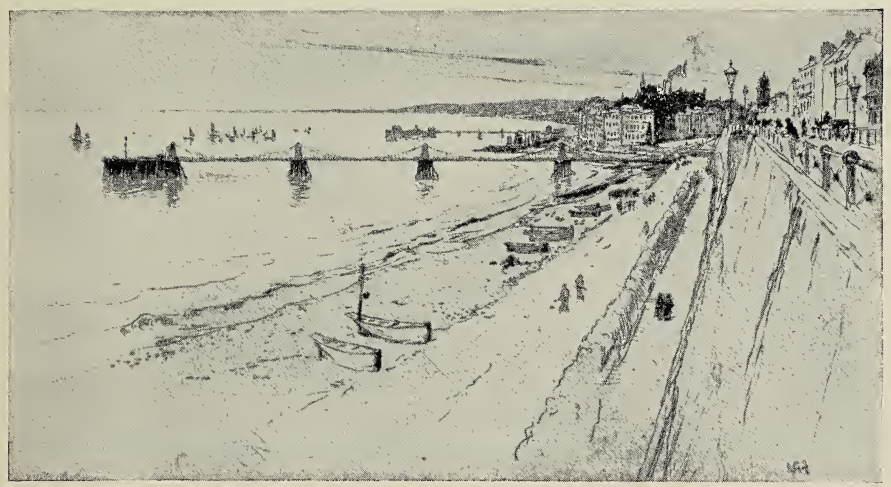

COLONEL GOFF.

"CHAIN PIER, BRIGHTON." 



\section{XVII.}

\section{GOFF.}

THE two contemporary etchers who in-

1 terest me most, among those I have not had occasion, yet, to write of, are two men unlike, perhaps, in nearly everything except in their possession of the essential quality of impulse-I mean the Frenchman, Monsieur P. Helleu, and our fellow-countryman, Colonel Goff.

No-when I said they were unlike in nearly everything but the essential quality of impulse, that was clearly an exaggeration. Another thing they have in common besides impulsiveness of temperament and spontaneity of effort-a love of beautiful and of free "line." Goff will show that in his studies of the hillside, of the shore, of foliage, of the tall grasses of the water-meadow, and of the winding stream; Helleu will show it in his studies of the most modern humanity, of the "Parisienne de Paris"all that is most completely of the capital, subtle, refined, over-refined-but with how 
extenuating an elegance!-or, now again, of the young grace of well-bred girlhood, as in a certain "Etude de Jeune Fille," with its wonderful union of Nineteenth-Century vividness with the grace of Reynolds or Gainsborough. And yet one other thing belongs to them in common-to these two men whose work presents, most certainly, in method as in subject, many a point of contrast. Both, being artists essentially, rather than merely skilled practitioners in a particular medium, swear no unbroken constancy to the art of the etcher-cannot avoid the keen perception and keen enjoyment of those "effects" and combinations for which it is not etching that affords the readiest or most appropriate means of record. And accordingly we have from Monsieur Helleu, pastels ; from Colonel Goff, water-colour, wash heightened with pen-work, or pencil drawings, marked sometimes with a strong accent, at others blond and suave as silverpoint itself.

Third-rate professional artists, and idle folk, or folk so busy that they have not had time to notice what good work has been done in Etching, and who it is that has done it, will at once discount Colonel Goff's labours because I call him "Colonel." But when I declare that he is, in the character of his work and in the fidelity and enthusiasm with which for years he has pursued 
it, no more of an "amateur" than is Sir Seymour Haden, he will be, I trust, even by the most commonplace of judges, forgiven the accident of military rank-his greatest crime being, after all, only that of having served in the Coldstream Guards. The offence may be condoned. Or, to speak seriously, I believe that military discipline, like the training of a surgeon bent on excellence in his own art, is, in truth, only an advantage. The strenuousness, the thoroughness, of good professional work, whether it be done in barrack or in hospital, in a city man's office or in the study of a writer, gives some guarantee of at all events the spirit in which the new work, the pictorial work, will be undertaken - a guarantee lacking in the case of the small professional painter, whose discipline in the arts of Life I must account to have been generally less complete. Yes, it is only fair to distinguish, when we talk about the "amateur"-and no one has less tolerance for the feeble amateur than I have - it is necessary to distinguish between the mind of the dilettante, of the idler, of the wishy-washy person who, from the high realms of an unbroken self-satisfaction, condescends occasionally to an art, and the mind of the trained and exact, and therefore of presumably the strenuous.

Ten years of frequent "joyful labour "Macduff's inestimable phrase-in the art of 
Etching have resulted in making Colonel Goff the author of some seventy plates, of which, to the outsider at least, the first characteristic will seem to be, the range and variety of their themes. The key to this lies in the sensitiveness of the artist, in his width of appreciation, in his reasonable enjoyment of scenes and subjects that have little in common, that present the piquancy of change. It is only figure-subjects proper that have scarcely ever been attempted by him; but in landscape, in marines, in town subjects, in subjects which involve now the expression of the passion of Nature, now the frankest introduction of every kind of modern detail of construction that is supposed to be ugly, and that the sentimental brushman declares to be "unpaintable," Goff is thoroughly at home.

Next to mere prettiness or "strikingness," what the public likes best in Landscape Art is not the record of Landscape's happy accident or of its intricate and balanced line, but the intelligible presentation of natural effects. That probably is why, among Goff's etchings, the "Summer Storm in the Itchen Valley" has thus far been the most popular. And certainly the public choice in this instance lighted upon work that was admirable and accomplished, spontaneous and effective-work not a little akin to that in Seymour Haden's admirable "Water- 


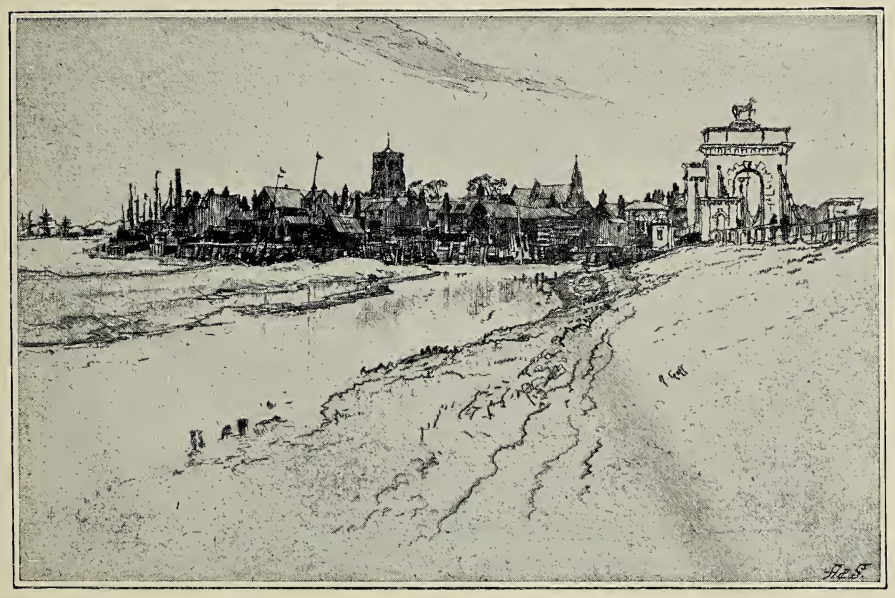



Meadow," work not proceeding to a conscious elaboration, yet not stopping short of the point at which even for the many it may be expressive. Its quality, however, good as it is, does not really give it a unique place in the list of Goff's labours; other plates-some that would be considered very humble ones-show virtues quite as valuable. Few etchers are Goff's equals, fewer still go beyond him, in composition of line, in arrangement of light and shade; and as he firmly possesses this science, it is natural that very many of his plates, and not only one or two of them, should satisfactorily display it. "Norfolk Bridge, Shoreham"-of which a reproduction is given here-displays it delightfully. The unity of impression is complete ; the grouping well-nigh faultless - there is the light arch of the bridge and the dark mass of clustered town behind it; church and houses and timbered sheds set amidst the winding of tidal waters; muddy shores, from above whose low sky-line there rises now and again the mast of a fishing-smack.

In "Winchester"- -a little plate of great simplicity and reticence-there is the note of a mood and of an hour, as well as of a place. Behind the flat meadows and the nameless stream that small trees bend over, there is the long line of the cathedral; and one feels over all the quiet of Autumn. Not 
a whit less admirable - a complete and satisfying picture, wrought with strength and delicacy - is "Pine Trees, Christchurch." Then there is the peace of "Itchen Abbas Bridge"--the little dry-point with the miller's house, the waving poplar, the granary, and the slow stream. In another plate, less personal, and perhaps less happy, but still good, there is the picturesqueness of the Lewes street; in the "Ford, Shoreham," complex activity, fullness of theme. In the "South Cone," the great broad waves that swing about the base of Brighton Pier, not only suggest the wind and moving waters that the title implies, but have a certain decorative quality, possible only when the process of "selection" has been just, and the visible labour somewhat sternly simplified. "The Chain Pier, Brighton," combines in high degree the charms of elegance and mystery. See the foreshortening of the steep, high wall, the delicacy of the Chain Pier and little fleet of skiffs, the reticent, suggestive touch in those grouped houses by the "Albion." "Charing Cross Bridge," by reason of its subtle arrangement, its victory over difficult material-more even than the "Métropole," with the dark cliff of masonry and the lighted lamps along the Brighton "front"- -is perhaps the best of all the several plates which are deliberately devoted to the treatment of such things as 


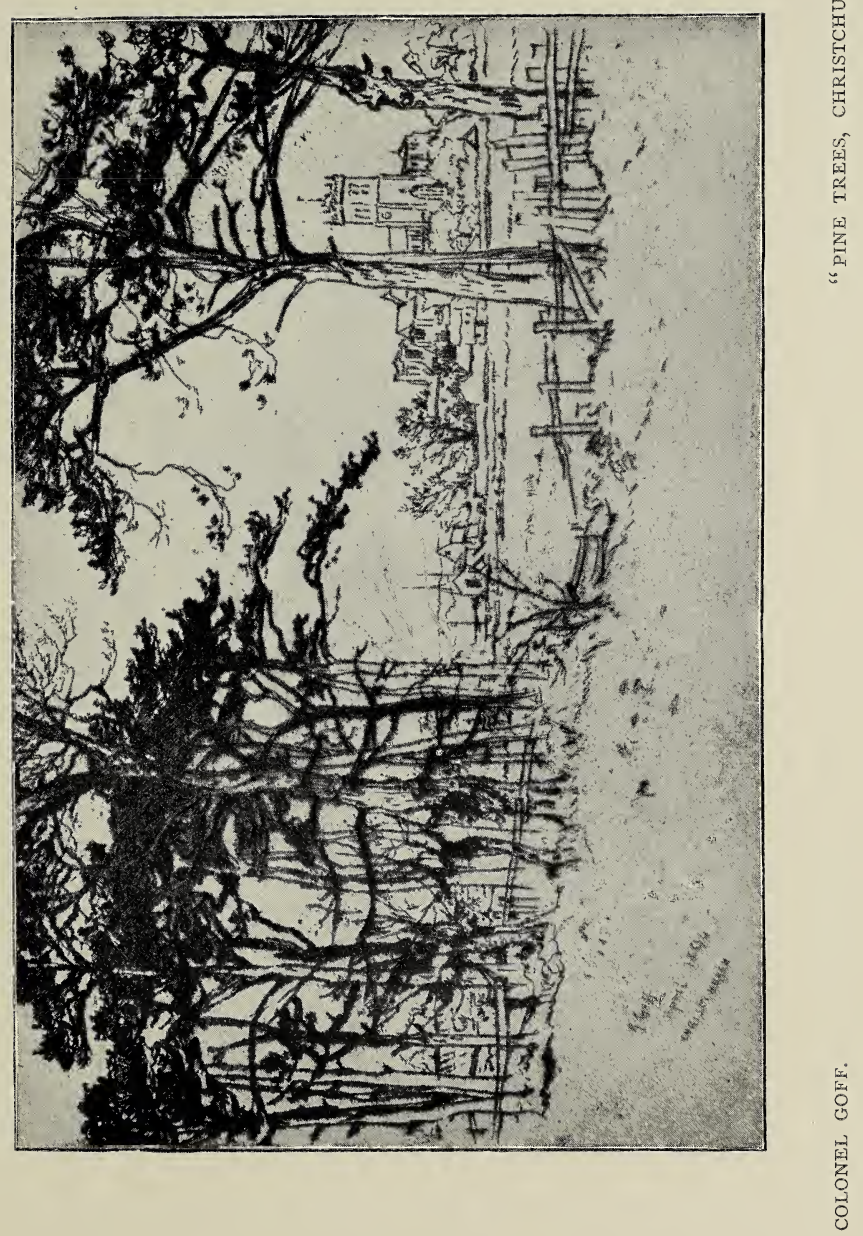



seem prosaic to the person whose poetry is conventional.

Most of Goff's plates give proof of thorough draughtsmanship, to the discerning; though nowhere is such draughtsmanship paraded or made obvious. In one most recent plate, however, devoted to a subject of which the inartistic, unimaginative mind, and the insensitive hand, would have made mere pattern-I mean the etching of the bared boughs of a weird apple tree-the draughtsmanship is, of necessity, and happily, conspicuous. But the thing is not pattern at all, and though we follow with delight the intricate line, there is the charm of an impression as well as the fidelity of a record. There is accent about the etching; emphasis, vitality; an atmosphere plays, as it were, amongst the boughs; the tree is not the tree only, but a part of Nature and the day.

Gœethe said to that disciple to whom he most fully unveiled himself,-- to the privileged Eckermann,--" "All my poems are 'occasional ' poems." In that resided their freshness, and Goethe knew it well. "All my etchings are 'occasional' etchings," could be said by nearly every fine etcher, too wise to set forth upon the picturesque tour with the deliberate resolution to perpetrate particular prints. For the art of etching, if it is to yield you its peculiar charm, 
must have been exercised-I cannot say this thing too often-only upon spontaneous promptings. There are very few exceptions. Méryon himself-that greatest genius, perhaps, in original engraving whom our Nineteenth Century has known, and one of the most elaborate of artists,--was not really an exception ; for, slow as his work must have been, the unity of impression preserved throughout so long a labour-the original impulse - was there, which the circumstance created. The spontaneity is essential. And few men better than Colonel Goff have executed spontaneous work with the resources of a firmly-held knowledge. 
${ }_{0}^{2}$

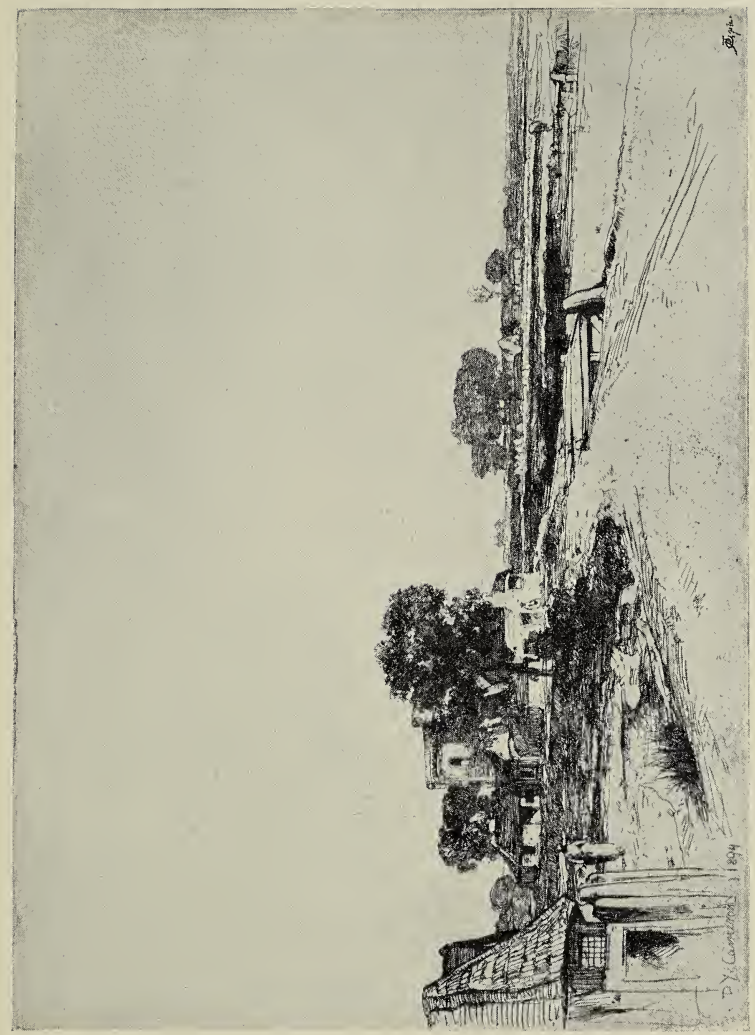

㸓 



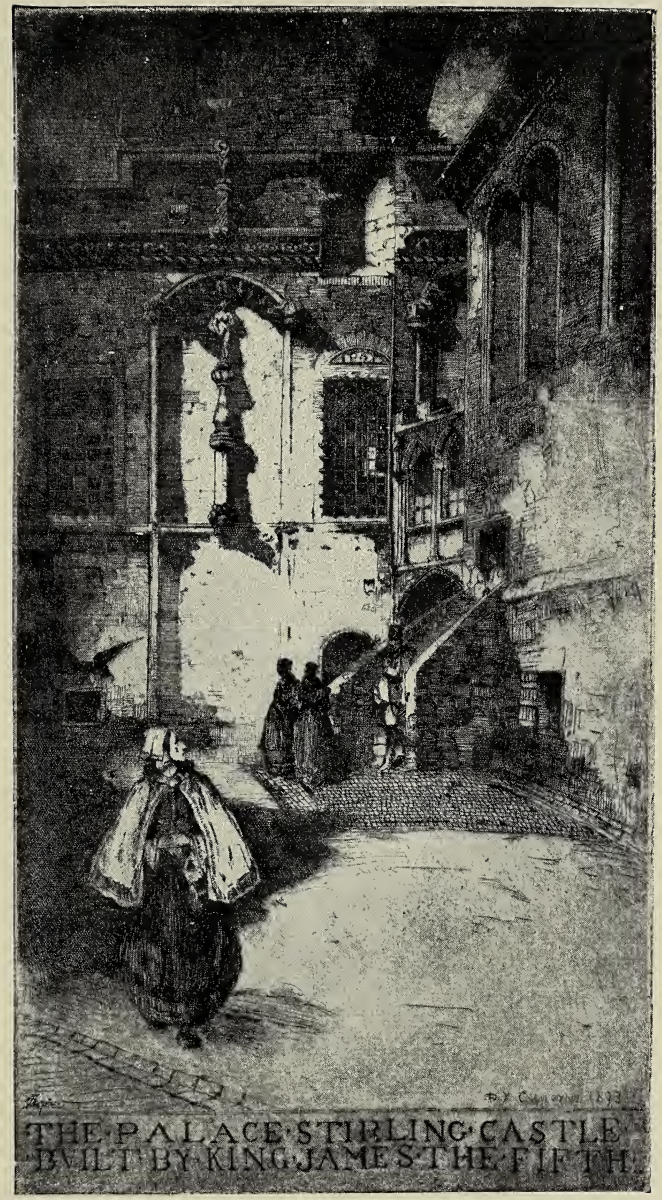

D. Y. CAMERON.

"THE PALACE, STIRLING CASTLE." 



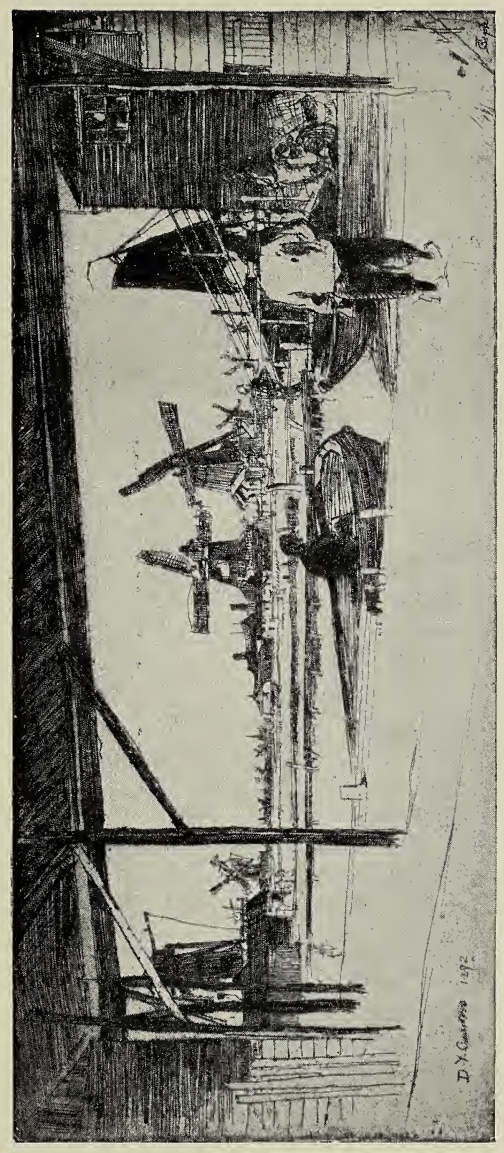



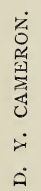





\section{XVIII. \\ CAMERON.}

7 HE amateur has had the opportunity I of looking lately a good deal at the prints of a young Scottish artist, Mr. D. Y. Cameron, who has himself, to do him justice, looked long and much at the prints of the masters. Though young, he has already been prolific, and has wrought not only many plates, but in various methods. Of course, I like his work as against that of men who, however gifted in other mediums of expression, are not essentially etchers. For Mr. Cameron is essentially an etchera fine engraver on the copper, above all things. Yet I cannot feel that any great proportion of his work, thus far, has quite enough originality or freedom ; and if he is to live and last as an original engraver-as I believe he may-he will have to acquire these virtues in yet larger measure. Meanwhile, here are a few comments on certain of the best of his most studiously wrought 
pieces, of which even the least attractive do not lack a workmanlike accomplishment.

"The Arch," a composition of curious shape-a tall, narrow plate-is a performance of solidity and brightness, although it shows that Mr. Cameron is apt to finish to the corners with a thoroughness too uniform or obvious-to be, indeed, like Mr. C. J. Watson, a little too positive and too material. In the "Flower Market," with its fleeting lights and shades, he leaves in part this positiveness. He makes an interesting experiment, but, after all, recalls the theme to which he addresses himself, only enough to assure you that the experiment has not been made in the medium that is fittest for it. "Colour, colour, colour!" you say. "The Palace, Stirling" - a dark forbidding interior-has certainly about it a grim Celtic imagination, and is individual in that. The oppositions of light and shade are at once strongly marked and skilful - their distribution quite successfully studied-in "White Horse Close." "The Dolphins" (I892) is full of vigour and vitality. Even better, perhaps, is "St. John Street, Stirling;" because its draughtsmanship is at once freer and more hesitating-not fixed and petrified, that is, but trembling with the semblance of life. And in the background of "A Rembrandt Farm," Mr. Cameron has wonderful reminiscences, 
both of the master's touch and of his way of looking at the wide-stretched landscape that he cared for the most. Nor does the plate suffer perhaps from being for once a deliberate imitation, successfully accomplished. Yet I admire Mr. Cameron more - my hope for his Future is more certainwhen I hold in my hand a good impression of his "Border Towers" - a composition of his own North country-a thing in which the inspiration has been very personal, and the fine work of detail has been obtained at no sacrifice of noble breadth. 


\section{XIX.}

\section{PENNELL.}

R. PENNELL is an extremely clever, 1 energetic, dexterous American, who has found profitable employment in our English land. He has shown himself to be a ready journalist in draughtsmanship. Drawing architecture and the scenes of the street, he has produced not a little art that is at once popular and tolerable; and he has even written about Art, dealing sometimes with far profounder people than his own order of mind permits him thoroughly to fathom. " Critic," therefore, I cannot call him, but able draughtsman, in a limited field, he unquestionably is.

A somewhat small proportion of $\mathrm{Mr}$. Pennell's work has consisted of etching, and in this he has shown, first, it appears, the influence of Seymour Haden, and next, the influence of Whistler. Had he but brought a personality to be enriched and fructified by great traditions! That, however, has been denied him; and, possessed 


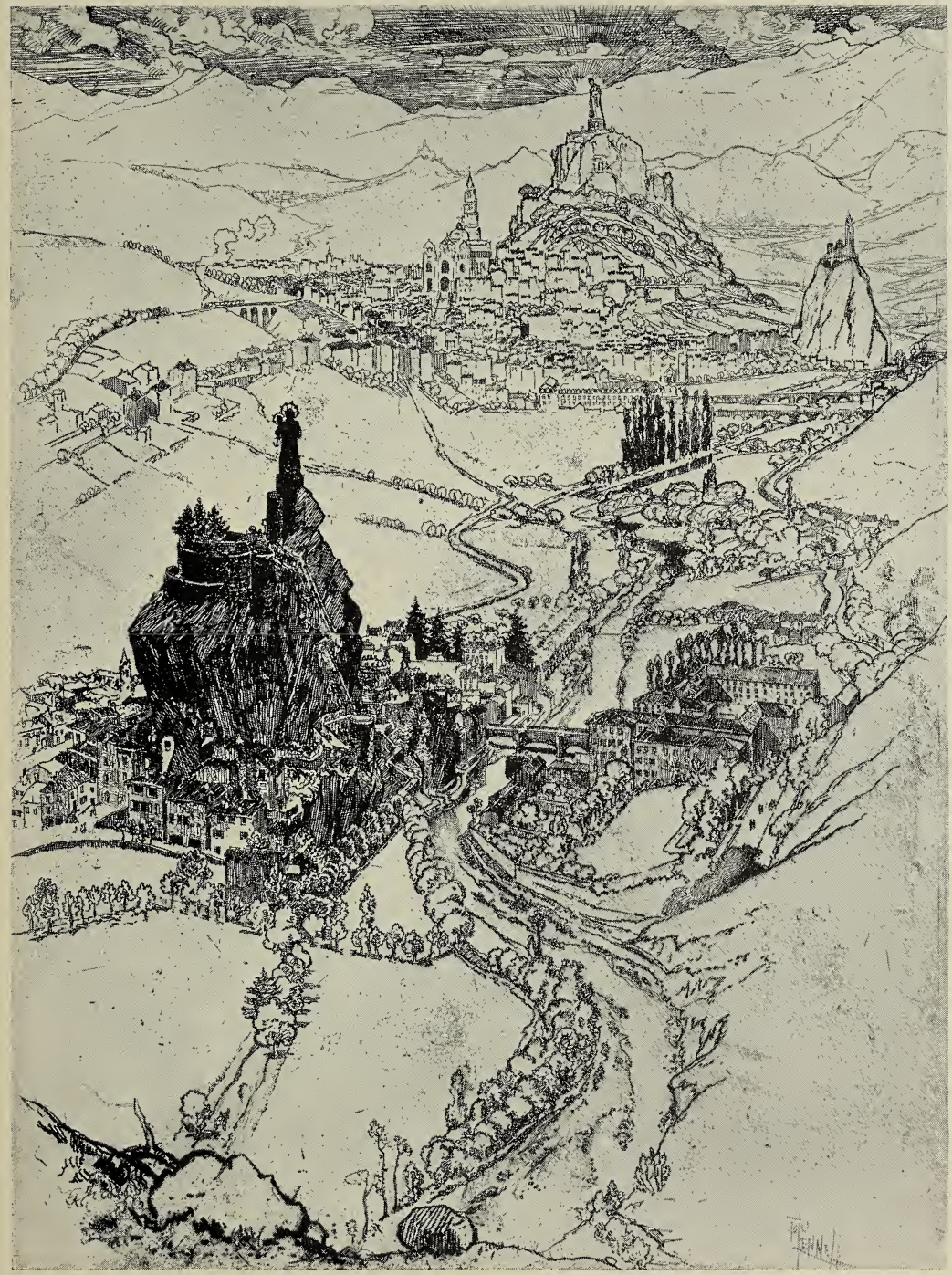



well of the grammar of his art, and of some of the best of its methods, he yet, as his own work reveals him, is, at times, uninteresting, since he is always unimaginative. Vista he has none. Yet, how good can his work be when the subject comes easily to help him! Nor is that seldom. The plate of "Le Puy en Velay," of which I give a reproduction, and which I like so much, recalls a noble Dürer background - takes our thoughts to those great elder masters who, from certain remarks that he has made about them, I judge that Mr. Pennell scarcely likes at all. It is the irony of circumstance. 


\section{XX.}

\section{MENPES.}

THOUGH Mr. Mortimer Menpes had 1 etched not a few coppers before he gave us the long series which recorded his impressions of Japan-and though, no doubt, he has etched from time to time since then-it is by the forty plates which constitute that Japanese set that he establishes his best claim to be regarded as an artist, serious and interesting. Traces of the Whistlerian vision, if not of the Whistlerian method, are perceptible in these memoranda of the people and the theatre, and of the long and low-built towns that stretch themselves sometimes along the edge of sleeping waters. But the art of Mr. Menpes is not all of it derivative. Something there is that is of himself alone, in the impression received and in the manner of its registration. $\mathrm{He}$ has economy of means, and yet abundance of resource. He is not merely a draughts- 


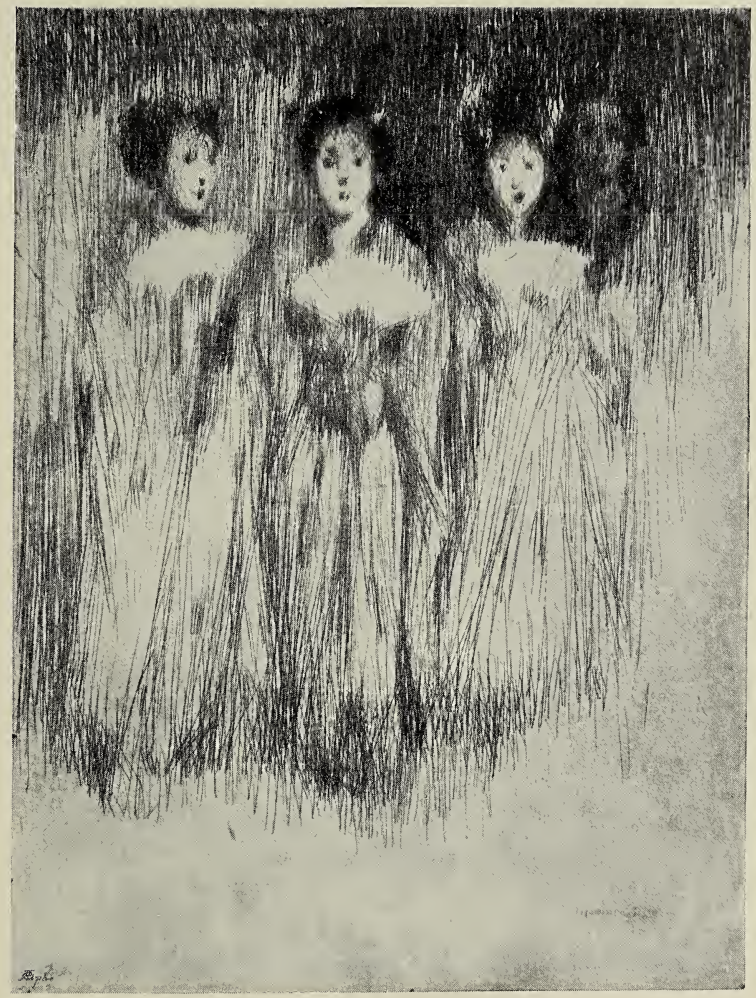

MORTIMER MENPES.

"JAPANESE GIRLS." 

MENPES.

man who has chosen to etch: he is an etcher whose feeling for the capacity of his particular medium has in it much that is instinctive. 


\section{XXI.}

\section{RAVEN-HILL.}

M R. RAVEN-HILL-the artist who 1 adds piquancy to comic newspapers -is little known as an etcher; but his work upon the copper is delicate, rightly precise and rightly free-it is in the best etcher's manner-and if it is as yet so little recognized, that is only because it is so scanty and has been so seldom exhibited. From several points of view the small array of Mr. Raven-Hill's etched work is interesting and valuable; it is, almost invariably, observant record and admirable craftsmanship; and not the least legitimate of its sources of interest lies in the fact that in it the presence of the refined artist, as distinct from that of the smart comic illustrator, is markedly asserted. Hereafter it may be that Mr. Raven-Hill will choose to etch, and to etch ably, scenes from the life of which, in other mediums, he has been, deservedly, a popular exponent. Tom, Dick, and Harry-Harriet, 

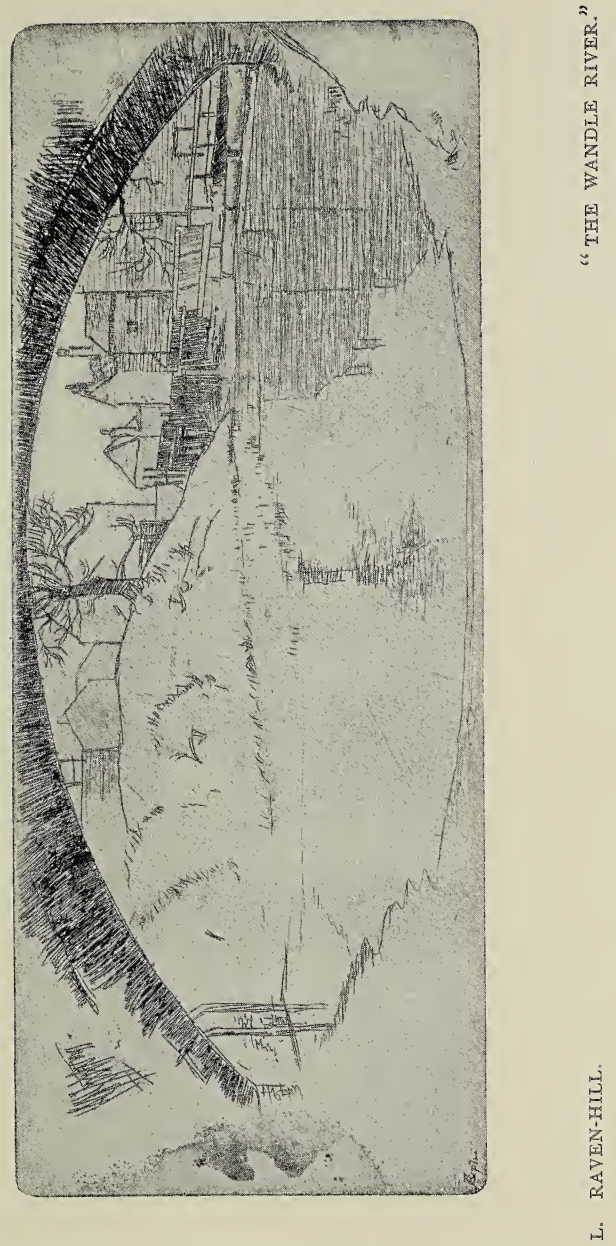

too, by all means-will then have their day upon the copper, nor will clown and cabotin be left out of the account. But, hitherto, the best of Mr. Raven-Hill's few etchings record scenes Whistler might have chosen, and do so with a touch and choice of line which, it may well be, that master might not desire to disown. 


\section{XXII.}

MACBETH AND HERKOMER AND AXEL HAIG.

SO much said, and yet nothing said of $\checkmark$ men a dozen times more popular than the generally single-minded etchers are wont to be, of whom in chief I have spoken. But to the large public, Macbeth and Herkomer and Axel Haig appeal without need of introduction-Macbeth and Haig appeal especially by treatment, and Herkomer especially by subject. Herkomer's theme is generally a dramatic one, and into it he introduces such obvious interest of line and of expression as may be found in a woman with the picturesqueness of age, a man comely and vigorous, a girl with Anne Page's "eyes of youth." Mr. Herkomer has a story to tell us-sometimes the story of a life as it is told in portraiture, and he tells it with no absence of ability. But attractive as he well may be, clever as he most surely is, he rarely reaches exquisiteness; nor is there reason to think that the plate, the needle, and the aquafortis constitute in any special way his proper 


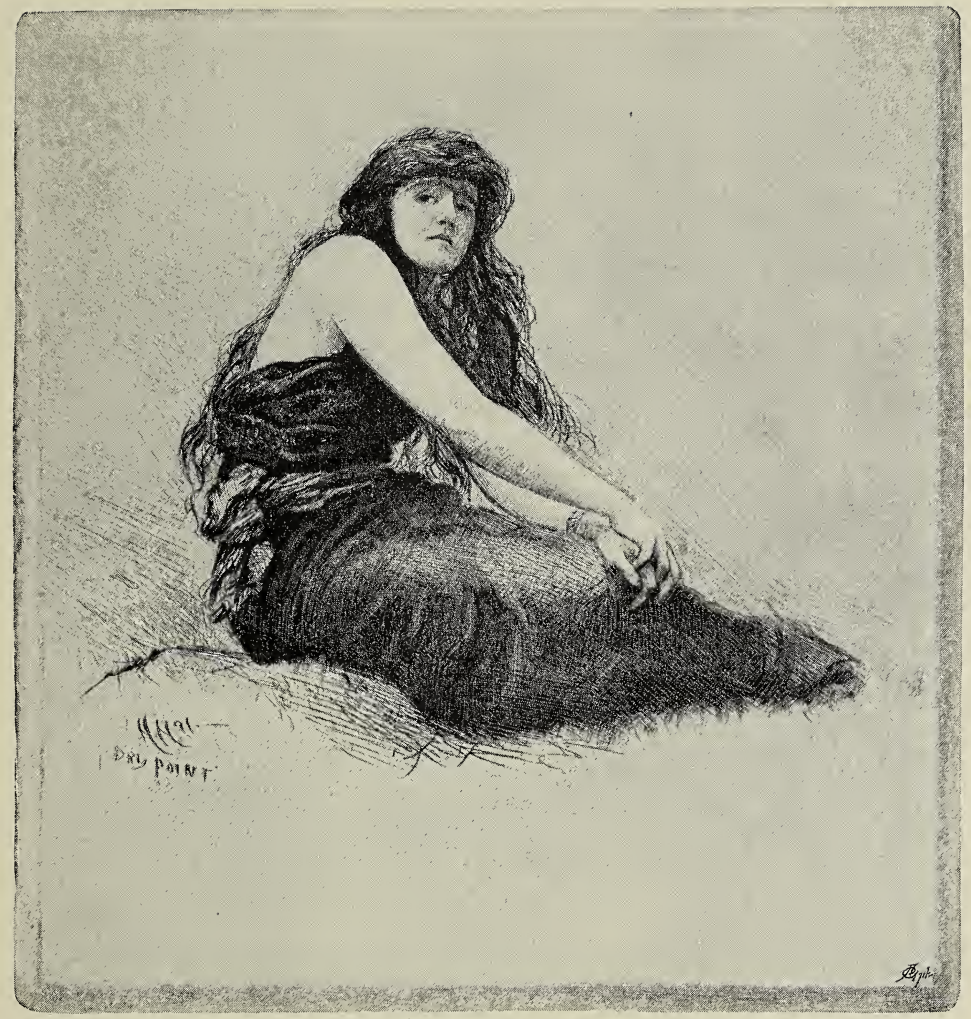

HUBERT HERKOMER, R.A.

"GWENDYDD." 

MACBETH, HERKOMER, AXEL HAIG. 155

medium. Still, one who is, as everybody knows, so spirited and energetic an artist - the author of so many a valiant experiment, the winner of an occasional triumph in the art of Painting, from the day of the "Pensioners" to the day of the "Burgomasters" - can be a graceful sketcher on the copper, when he likes, or from time to time, at all events.

Robert Macbeth's inventive work in etching does not want originality; but it is not the originality of an etcher, in method or vision of the world, but rather the originality of his own painted pictures. These, or the effects of them, elaborate and interesting, he reproduces, as far as may be, in the print. For nearly twenty years he has, from time to time, etched his own conceptions, and during much of this long period the public has surely benefited by his able, dexterous translations of great or charming masters, from Velasquez to Mason. A certain proportion of his original work upon the copper was performed-and not indeed unnaturally-before Mr. Macbeth became familiar with the technical resources of the craft. Thus, the "Potato Harvest" -an interesting subject, and treated, as to its composition, very characteristically - is, as an etching, grey and colourless. "The Cambridgeshire Ferry" (of I88I), with that free, swinging, rustic girl he likes to paint, 
has excellent points about it, and would be called " important" by a dealer. Later, "A Cast Shoe" is luminous as well as elaborate. "Flora"-a print of I882-is very spirited and rich, and has the sentiment of the morning. But I am not sure whether the purist in the etcher's art would not like most of all the rapid and indicative sketch of "A Flood in the Fens." It is a slight study, with the rare note of action and of tragedy - a free dramatic record.

Mr. Axel Haig, the third of these popular and long accepted artists, has no painted pictures by whose method he may be inspired-he is unlike Robert Macbeth in this respect-but his able etchings of architectural subjects are nearly all of them, nevertheless, finished up to the corners. So much is actually set forth, with such elaborate and skilled pains-all the work being perfectly evident, no labour of omission having been undertaken, and little labour of choice-that the imagination of the spectator has hardly a chance of exercising itself. His intelligence, alas! is wellnigh unnecessary. And yet, as you look at the long record of buildings whose aspect has been grasped and presented by Mr. Haig with diligence and skill, you must respect, in the artist, much of his craftsmanship, and his great German quality of untiring and sagacious effort. 


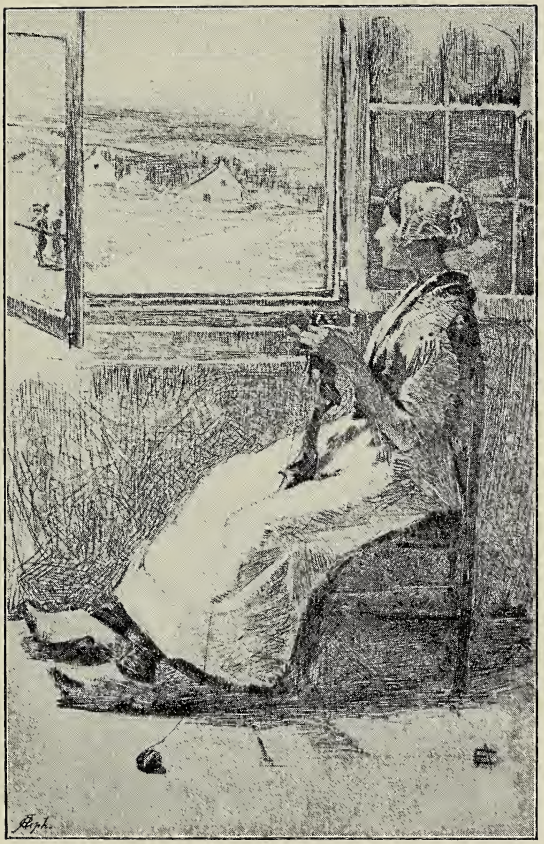

E. A. ARMSTRONG (STANHOPE-FORBES).

"THE OPEN WINDOW." 



\section{XXIII.}

SOME OTHER ETCHERS.

I CANNOT pretend that the artistic in-

1 dividuality of Elizabeth Armstrong and Minna Bolingbroke (now Mrs. Stanhope Forbes and Mrs. C. J. Watson) is yet sufficiently marked to allow either to be the subject of a critical essay; but in the record of an Art in which-as in so many others -it seems generally to be decreed to women, "Thus far, and no further," it is useful and satisfactory to note the closeness of observation and the skill of hand possessed by these two ladies. In Miss Armstrong the world some time ago recognized a particularly dainty draughtswoman; and the little print which is submitted here as an example of her talent, is a refined Genre picture. To Genre, too, belongs that which, so far as I have had the opportunity of knowing, is the happiest effort of Miss Bolingbroke. It is singularly good; the subject chosen pluckily, where only a Modern would have ventured to find it; 
and then the theme pictorially conceived, in the true etcher's spirit-this admirable little dry-point is a vision of the factory, broad, luminous, and rich. One or two other dry-points by the same artist-drypoints of plump birds, and live stock of the farmyard-suggest the possibility that in her quest for themes Miss Bolingbroke may follow in the track of a great Frenchman, and may meet with a success akin to some extent to that of Bracquemond's masterpiece, "Le Haut d'un battant de Porte."

Mr. Percy Thomas-a graceful draughtsman of ancient English buildings, and of the incidents of the River-must be reckoned almost as of the Old Guard, amongst the etchers of the present generation. $\mathrm{He}$ etched before Etching became fashionable; and now that he has long been beset with friendly and accomplished rivalry, he yet proceeds to make additions to the bulk, and perhaps even to the range, of his labours. An inequality more marked than any we are wont to perceive in the work of an important master, tells, perhaps, to some extent, against his position. And though his manner is often pretty, and is generally refined, it is but seldom distinguished. He has worked, it may be, too much, and, it may be, not always in obedience to the spontaneous prompting. Yet his methods 


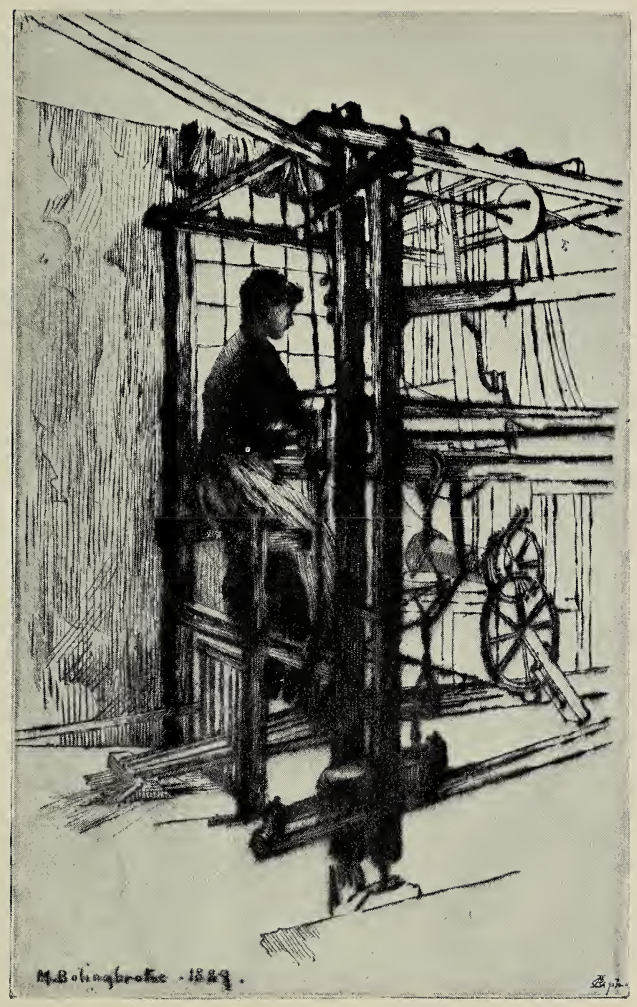

M. BOLINGBROKE.

"AT THE LOOM." 



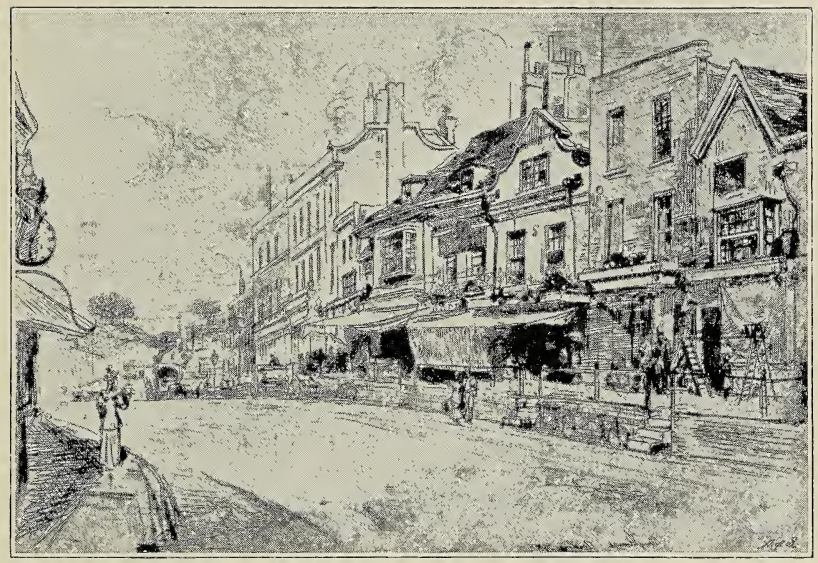

PERCV THOMAS.

"DORKING." 

have ever been legitimate, and he has attained grace. His "Dorking"-with its long perspective of the sunny street in some hour of the summer afternoon-is a piece of agreeable and capable, and even of elaborate, sketching ; and his "Old Lighthouse, Hastings"--one of the most entirely satisfactory of his coppers-has the charm of an admirable composition conveyed by simple and certain means.

Among the other aquafortists practising from time to time amongst us-not to speak of the more recent of the promising recruits to the Society of Painter-Etchers, who have yet to make their history-mention should not be altogether omitted of Mr. W. L. Wyllie, whose popular marine subjects need evoke no opposition, even where, as exhibitions of the etcher's art, they scarcely deserve to attract.

Again, there is Dr. Arthur Evershed, a ready and sensitive draughtsman with the needle, whose "Marsh Farm" is only one out of a score of evidences of his refined enjoyment of the quiet lines of uneventful lowland landscape. Sir Charles Robinson and Dr. Propert need by no means be forgotten. Mr. J. P. Heseltine has not perhaps exhibited much of late; but he, as long ago as when he wrought that series of Etchings Mrs. Noseda published-it was some twenty years since-gave ample proof 
of his placid, sympathetic observation of the ordinary land, and of his ability to record the charm he was not tardy in feeling. The etched work of Mr. Holmes May is, most of it, I think, more recent. It is a vigorous, independent sketching of landscape. It notes tree-form with energy and sky effects with refinement.

That potent, brilliant, but eccentric Spaniard, fashionable naturally among the younger men for his unquestioned audacity of talent-I mean, of course, Goya-has been, it would appear, the chief inspirer of a few clever prints done recently by Mr. Rothenstein, in frank, fantastic illustration of Voltaire's "Pucelle d'Orléans." In Mr. Rothenstein's few things-too few as yet to permit us to really judge him as an etcher -we see, along with some inventiveness which is the artist's own, not only Goya's style, but Goya's method-an effective, dexterous mingling of the etched line with aquatint.

Again, the Whistlerian spirit finds appropriate expression in the vivacious prints of Mr. Walter Sickert and of Monsieur Roussel - many of them engaging, interesting, and unconcealed impromptus, towards which any word of adverse criticism would be but ill-addressed. And, lastly, ere I turn to treat at greater length the work of one who is a born etcher, and an etcher chiefly- 


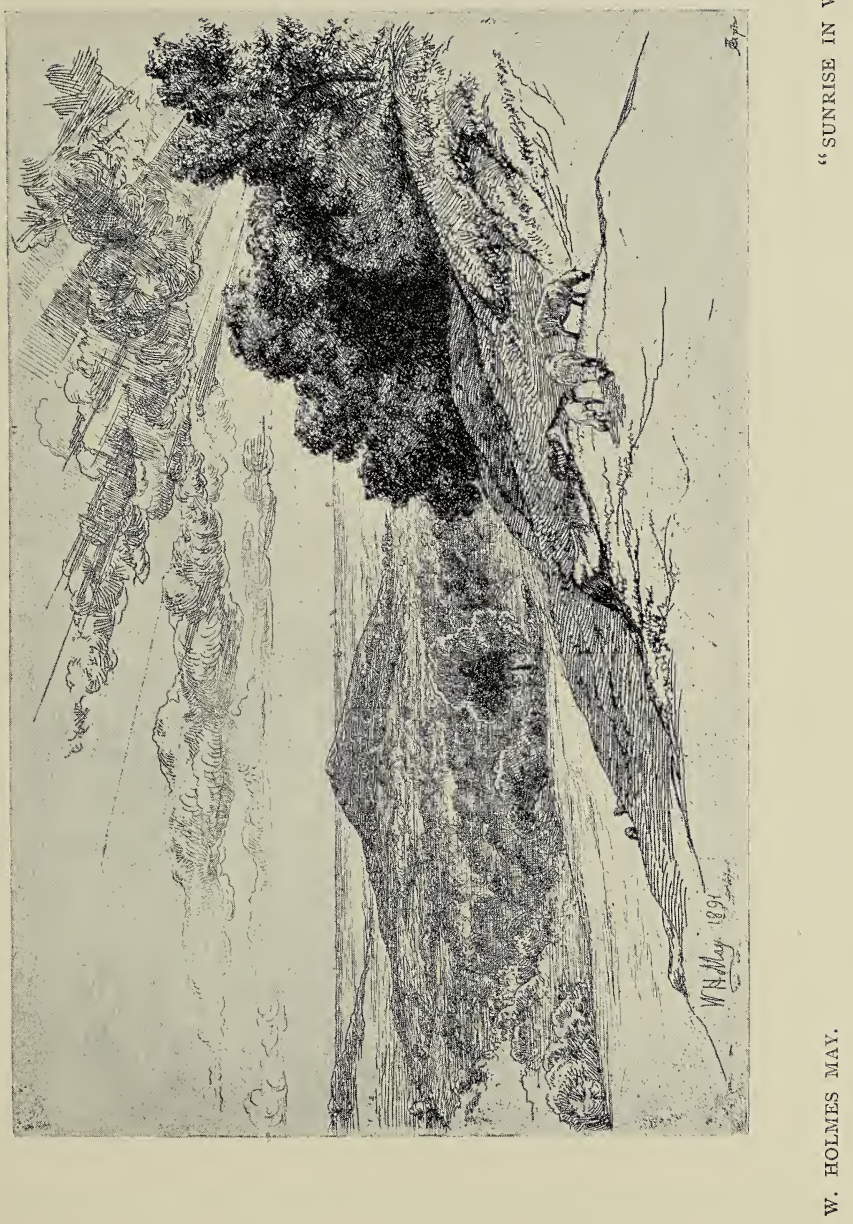





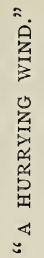

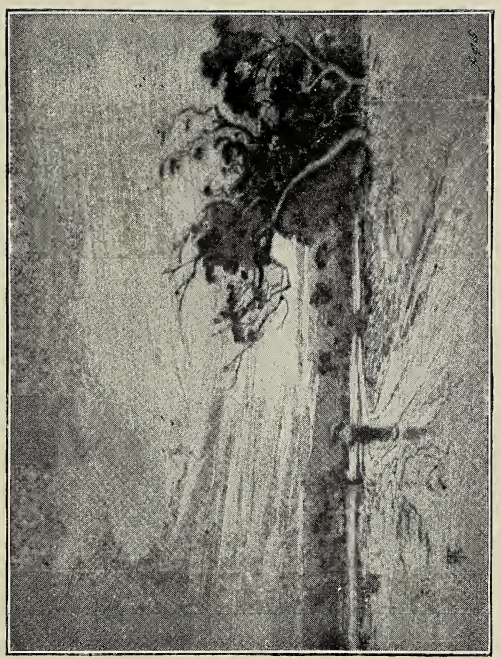

落 

SOME OTHER ETCHERS.

I I I

Monsieur Paul Helleu-let there be brief recognition of the true artist's instinct which caused Mr. Alfred East, our admirable landscape painter, to record, with the solidity and massiveness so possible to dry-point, his impression of "A Hurrying Wind." 


\section{XXIV.}

\section{HELLEU.}

THE copper on which some master of 1 etching will, sometimes in an hour, engrave in dry-point the latest of his conceptions, the newest impression he has received from the world, is, like the pages of a draughtsman's sketch-book, the revelation of just that thing that strikes him the most. The character-in a sense, the temperament-of the artist is betrayed or hinted at by his selection; notwithstanding that the selection, if the man is wise at all, owes something to his knowledge of what are the bounds of his capacity. The work of the great etchers-Rembrandt apart, and he was practically unlimited-shows this. The subtleties of the figure interested Sir Seymour Haden less than the curve of a great stream, the light and shade in an old garden, or the broken surface of a Dorset heath. It is, at least, not emotional incidents that have been the mainspring of the art of Mr. Whistler; for he has been 


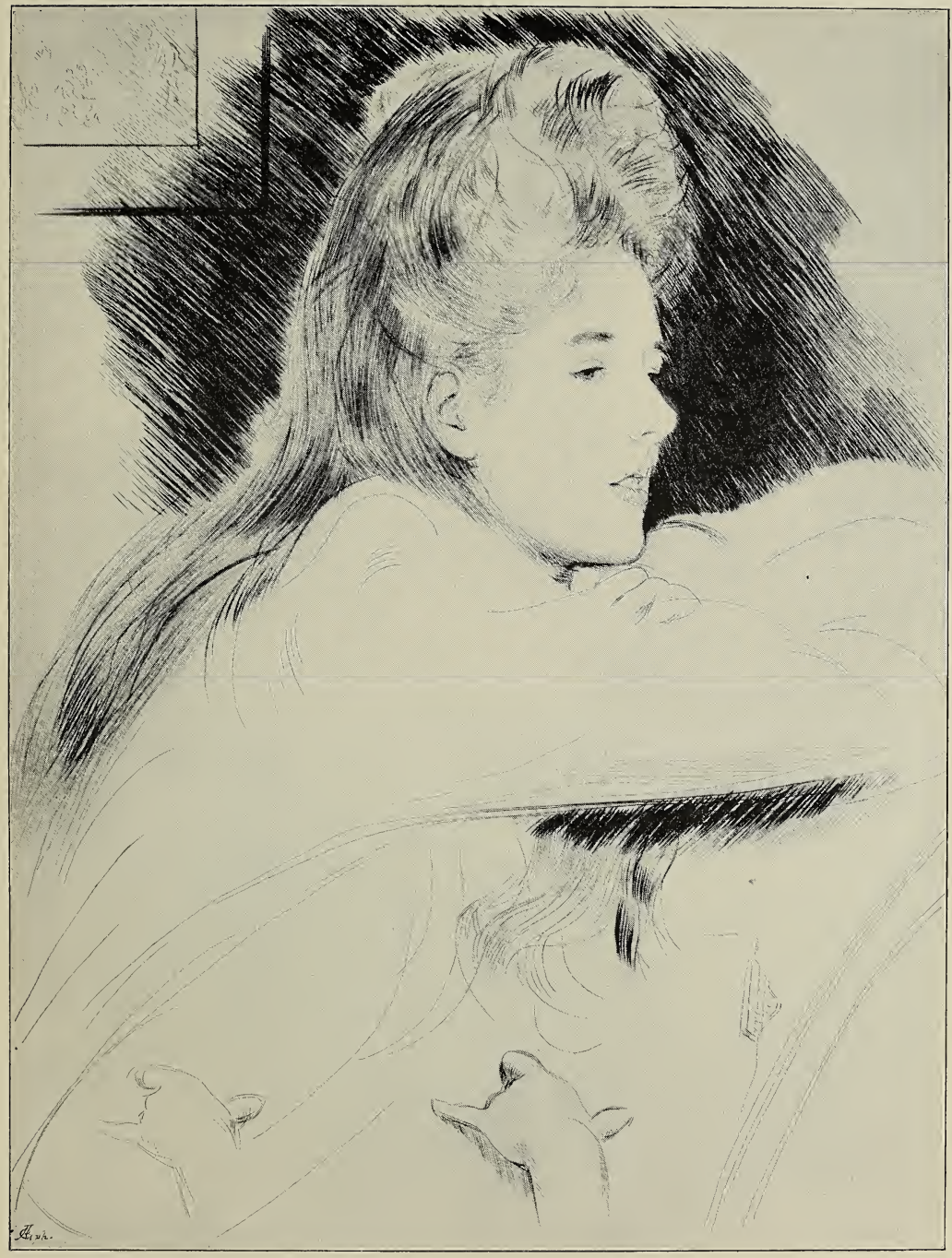

HELLEU.

"ÉTUDE DE JEUNE FILLE." 

inspired by the material that he was readiest to receive. And so in the work of that brilliant artist in dry-point to whom I turn last of all, there is evident the sign of his own leanings, the engaging suggestion of those things in his daily life which he most sympathetically notes. And M. Helleu is, above all things, the recorder of the beautiful or the refined interior, with its charm of artistic and harmonious detail-its charm, above all, of feminine life, or of the life of children.

It is as an artist working in pastels that M. Helleu-a man still in young middle age-happens to have been longest known. And his pastels have, not unnaturally, been for the most part portraits. In them he has evinced, and more, it may be, than in his latest portraits in dry-point, the skill of the likeness-taker. But likeness-taker merely he has never aimed to be; the artist has invariably asserted himself, and, if in nothing else, at least by this or that dexterity of craftsmanship-fine jugglery of execution. Only four or five years ago did it occur to M. Helleu to turn to the processes of the engraver, and to sketch rapidly on copper-he turned to dry-point. He has found in England much appreciation; he has worked here to some extent; and his contributions to the Society of Painter-Etchers have been frequent as well as delightful. 
In Paris, M. Helleu was much associated with M. James Tissot, an artist whom Englishmen knew as an etcher in almost the last generation. To the association with Tissot - a bold and sometimes graceful recorder of contemporary life with the etching-needle-is due, I have no doubt, M. Helleu's first practice in dry-point. To some extent he has seen the same world as Tissot, but he has seen it always in his own way, and has pourtrayed it with a singular economy of means that marks him as the brother of the greatest in etching. Tissot, with all his virtues of independence and vigour, has shown little of this economy, nor has he displayed the peculiar refinement which counts for so much in M. Helleu's charm. Briefly, this is a case in which the pupil-if pupil you can call him-has improved upon the master. It has been given to M. Tissot to have some share in the formation of a craftsman more subtle, a poet far more sensitive, than himself.

Up to the present time, some seventy or eighty plates have been executed by the brilliant and delightful sketcher, M. Tissot to some extent formed. Scarcely one of them, I think, has involved more than a single sitting on the part of model or artist. An hour or two of strenuous, enjoyable, untired labour has sufficed for the production of each dainty, each masterly, work. In 
2 

an hour or two the lady or the child of M. Helleu's choice has found herself recorded on the copper-she and whatever accessories were deemed desirable to indicate her milieu, to place her amidst the surroundings which assist in the telling of her story. There is not, as far as I am aware, a single piece of M. Helleu's that is not a figure subject, and among his work, so far as it has yet proceeded, I do not recollect a single portrait of a man. Edmond de Goncourt calls his dry-points "les instantanés de la grace de la femme""snap-shots," shall we translate it, at the charm of modern womanhood-the womanhood of the drawing-room- "snap-shots," not less often, at the charm of refined childhood. In Helleu's etched work, the connoisseur will welcome what is practically the complement of the etched work of Vandyck, who, in his score or so of plates (wonderful painter though he was of women), undertook only the portraiture of certain distinguished men.

Helleu's method of dealing with his subjects is not always, or even very often, the method of direct portraiture. His conception has a certain affinity with that of the artist in Genre, in that the model or models, be they women or children, do not only stand for their portraits, but are discovered in poses which suggest an incident this 
moment happening-be it only the incident of a woman having her hair brushed, of a girl struggling into her jacket, of a woman stooping forward over the drawing-room fireplace, of a child playing with its toys. Helleu's models are not long stationary, their attitude is never stereotyped; what he pourtrays mainly is movement now making, or movement only just arrested. Hence, perhaps, the sense of spontaneity in all the work-the sense, when you have looked through his plates, that you have been living in the intimacy of charming people who in their daily ways turn this way and that, stoop, stretch themselves, smile, get suddenly grave, dress themselves, lift their eyes inquiringly, or toss the great long hair upon their shoulders. Their movements, whatever they are, are made with the immediate freedom, the complete absence of self-consciousness, of well-bred, natural folk -the folk whose presence, even when they are not actually handsome, or when no personal affection binds them to you, gives a legitimate charm to the passing hour. The spectacle of the world is pleasanter when it is they who are on its stage.

Helleu's etchings prove him to be in sympathy with the most alert, which is often also the most dignified and distinguished of modern youthful beauty. I know of no plate of his in which he has realised the 


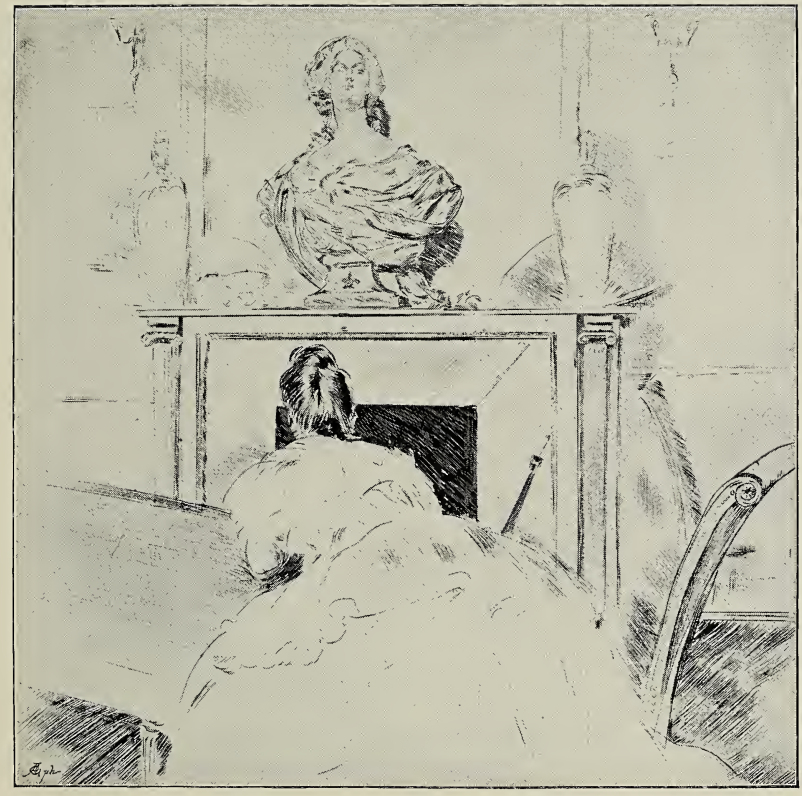

HELLEU.

"LE SALON BLANC." 

dignity of age as Rembrandt realised it in the etched portrait of his mother smiling, and in that other etched portrait of his mother, with a black veil and folded hands. But several times Helleu has realised what Whistler realised in the dry-point of "Fanny Leyland"--the dignified beauty, the reticent tenderness, the mood, courageous or contemplative, of the better order of young girlhood. Admirable in this way is that "Etude de Jeune Fille," which shows the quick and earnest, fearless glance-the girl with the lifted elbow and the streaming dark hair. Hardly less admirable, that other study of a child a little younger, the head on a large scale, and the head alone. It may be added, as a detail of both these rare plates, that no others, either by $M$. Helleu or by any other etcher, show quite so obvious a mastery in the treatment of hair. Dry-point, as M. Helleu handles it, would seem to have been made for the magical suggestion of all that you may notice in hair, except its colour-of its flow and texture, weight and life.

"Femme à la Tasse," a study of two uplifted hands, holding between them, lightly, in the fingers, a porcelain cup out of which the reclining figure drinks, is a most delicate arrangement of "line," and of amazing economy of means. And the "Salon Blanc," or one especially of the several 
plates which bear that name, is to be noted not for the figure only, not, perhaps, for the figure even chiefly, but for the brief and dainty suggestions of tasteful furniture, the line of a screen, the mouldings of a mantelpiece, the curve of a girandole.

We have etchers amongst us, and clever ones, too, to whom the presence of character in their living models, and in those models' backgrounds, has been, above all things, precious; to whom the presence of the eccentric has been valuable, and the presence of beauty, superfluous, not to say burdensome. But, with M. Helleu, beauty-beauty of no conventional order, the rapid charm of movement, of expression, of contour-is the inspiring and satisfactory thing. He lives in its intimacy And he reveals it-much as Watteau did, yet in ways how fearlessly modern!-to the spectator of his work. 
MR. WEDMORE'S SHORT STORIES.

Each vol. 3s. 6d. net.

PASTORALS OF FRANCE.

Fourth Edition.

RENUNCIATIONS.

Third Edition, with portrait by J: J. Shannon.

ENGLISH EPISODES.

Second Edition. 


के 


$\gamma_{h, g_{0}}$ 
